\title{
Using Purchase Restrictions to Cool Housing Markets: A Within-Market Analysis
}

\author{
Tsur Somerville ${ }^{\dagger}$ \\ Long Wang $\ddagger$ \\ Yang Yang§
}

This version: September 28, 2018

\footnotetext{
${ }^{\dagger}$ Sauder School of Business, UBC. 2053 Main Mall, Vancouver, BC, V6T 1Z2, Canada. (email: tsur.somerville@sauder.ubc.ca ).

${ }^{\ddagger}$ School of Entrepreneurship and Management, ShanghaiTech University, 393 Middle Huaxia Road, Pudong, Shanghai, China 201210 (email: wanglong@shanghaitech.edu.cn).

${ }^{\S}$ School of Hotel and Tourism Management, CUHK Business School, The Chinese University of Hong Kong, 12 Chak Cheung Street, Hong Kong SAR (email: zoeyang@cuhk.edu.hk).
} 
Using Quantity Restrictions to Cool Housing Markets: A Within-Market Analysis

\begin{abstract}
In response to worsening housing affordability resulting from rapid housing price appreciation, governments in some high housing price areas have introduced taxes or restrictions to reduce investment by non-residents in residential real estate. We study the effectiveness of these efforts using the restrictions imposed by local Chinese governments in November 2010 on apartment (condominium units) purchases. Our contribution comes from using data that exploits within city variation in restriction implementation to better control for unobserved city differences and the incorporation of land auction data to identify the supply effect of these policies. Our results suggest that restrictions on non-owner-occupant purchases significantly reduce activity levels by approximately $40 \%$ in the short run, compared to areas without restrictions. These effects diminish with time. However, housing price changes are not different between restricted and unrestricted areas. The results operate via end-user demand and not through the land market and the subsequent supply response by developers as neither the number of land auctions or prices paid for land have differential changes between districts with and without purchase restrictions.
\end{abstract}

Keywords: House prices, government restrictions, Chinese housing market

JEL Code: R21, R28 


\section{Introduction}

Since the financial crisis, housing prices in a number of cities have experienced significant growth. In response to dramatically worsening housing affordability resulting from house price inflation, local residents have targeted their ire at residential real estate purchases by non-residents, as they perceive external capital flows to residential real estate as a primary cause of the affordability challenges 11 Governments in Australia, Canada, Hong Kong, Israel, and Singapore have placed higher purchase taxes on non-resident buyers. The United Kingdom and New York have changed the tax treatment afforded non-resident owners. Switzerland has restricted the number of units available for investor purchase. The new government in New Zealand in the summer of 2018 introduced severe limits on foreign investment in residential real estate, similar to Australia's restrictions that limit non-residents to purchases in new developments only:2 While the calls for action have been strong, the evidence on the effectiveness of these type of policies at addressing overheated markets is somewhat sparse. In this paper, we use within city variation in Chinese market tightening policies to evaluate the success of these types of restrictions on investor demand in cooling housing markets and moderating rapid house price appreciation.

In late 2010 and early 2011 in the midst of a nationwide housing boom that grew from expansive policies following the world financial crisis, the Chinese government introduced measures to calm local housing markets. Beyond macro-prudential directives affecting mortgage interest rates, mortgage underwriting criteria, and access to mortgage credit, the Chinese government also directed municipalities to limit the number of properties a household could purchase. These restrictions targeted investment, preventing buyers, depending on their residency status, from purchasing either a second or third property ${ }^{3}$ Unlike the macro-prudential policies that were imposed on all significant cities and applied to all buyers, the purchase restrictions were enacted with variation: some cities did not introduce restrictions at all, while in others the implementation varied by location within the city. We exploit the latter within city variation in these restrictions using development project level data to test the effects of the purchase restrictions on house prices and transaction volumes.

In both western markets with rapid price appreciation that have worsened affordability

\footnotetext{
${ }^{1}$ See Bryant, C. in Bloomberg Opinions, Aug 18, 1918 for a synopsis: https://www.bloomberg.com/view/articles/2018-08-20/can-t-afford-a-house-blame-the-apocalypse.

${ }^{2}$ This is distinct from long standing restrictions in many areas of non-resident purchases of "sensitive" oceanfront or agricultural land.

${ }^{3}$ Much of this is not for rent. A Southwest University of Finance Study reported $20.9 \%$ of housing units unoccupied in 2011. As reported in Wall Street Journal, June 11, 2014, https://www.wsj.com/articles/morethan-1-in-5-homes-in-chinese-cities-are-empty-survey-says-1402484499.
} 
for local residents and in Chinese cities the concern is that investors who purchase residential real estate for capital appreciation or as a store of wealth and not income flow are distorting housing markets away from local incomes.4 Non-residents and capital inflow that support this type of purchase could cause local house prices to reflect larger asset markets rather than local labour markets $5^{5}$ By limiting investor demand, the hope of governments that have imposed purchase taxes or restrictions is that this will stop price appreciation and lead to corrections that bring markets back in line with local demand. The research question then becomes what is the effect of these policies on housing markets.

The contributions of this paper to understanding the effects of government actions to calm housing market stem from both a better matching of data to the identification strategy and supply side estimation using data from local government land auctions. In comparison with other work, we are able to execute difference-in-differences (DiD) tests at a fairly granular level of geography, obtaining identification from the differences in changes between different districts within a city. This allows us to circumvent better the bias problems from non-random treatment, because of the endogeneity of housing market conditions and policy actions, that occur with the cross country or inter-city analyses of housing market interventions in the extant literature. We argue that any unobserved patterns correlated with selection are likely to be more acute across cities than within cities because the latter share the same housing and labour markets. Our approach remains subject to problems with non-random treatment and inter-group differences because the allocation of district to treatment (restrictions) or non-treatment (no restrictions) is tied to the area's distance from the city centre. We believe this to be a less acute violation of DiD assumptions. As well, our findings survive a variety of robustness and falsification tests that support the causality we cite.

The second aspect that sets this work apart from others in the area is that we are able to test for supply effects..$^{6}$ The land supply data yields results on local government and developer behaviour that serve to assess the price and volume effects in the apartment unit market. By using data on land auctions we test whether developers reduced their bids for

\footnotetext{
${ }^{4}$ Mufson, S. "In China, fear of a real estate bubble." Washington Post, Jan. 11, 2010. http://www.washingtonpost.com/wp-dyn/content/article/2010/01/10/AR2010011002767.html. And more recently Balding, C. "Why China Can't Fix Its Housing Bubble." ]Bloomberg Opinions, June 24, 2018. https://www.bloomberg.com/view/articles/2018-06-24/why-china-can-t-fix-its-housing-bubble.

${ }^{5}$ Favilukis and Van Nieuwerburgh (2017) model a city housing market with local residents and nonresident investors, demonstrating the effects on prices and welfare loss from capital inflows when investors neither occupy nor rent out the apartments they acquire.

${ }^{6}$ We use buildable area $=$ maximum allowed floor area ratio $\mathrm{x}$ land area as our quantity measure of the supply from a given land auction rather than land area as it better reflects the potential amount of apartments that could result from the auctioned land.
} 
land, consistent with an expectation of long-term decline in demand, or local governments reduced the volume of land and potential buildable floor area they introduced into the market, in which case local policy objectives would match the national priorities. Both allow us to ascertain more clearly whether the apartment market outcomes reflect changes in demand or whether supply side effects are also present.

We find that quantity restrictions have substantial immediate effects on transaction volume but no effect on residential property prices. In the six months following the introduction of quantity restrictions, transaction volumes in the districts within a city with purchase restrictions fall over $40 \%$ relative to volumes in unrestricted districts. Over time this difference declines in magnitude, to $30 \%$ for a twelve month window and $24 \%$ for a two year window. In contrast, the difference in the change in house prices pre-and post-policy between these two areas are not statistically different from zero over any period in our data. The results are robust across tests comparing districts as a whole and if we use a border discontinuity approach and limit the sample to developments within a $3 \mathrm{~km}$ band on either side of the border between restricted and unrestricted districts. Falsification tests on using placebo dates and district boundaries for timing and location yield null results, supporting the argument that the quantity restrictions were responsible for the differences in transactions volumes. In comparison to our results, studies using cross-city panels, find higher volume effects and that residential real estate prices in cities with restrictions fall by over $10 \%$ when compared with cites without such restrictions.

The land supply tests on land auction prices and volume show no statistically different from zero differential changes in the number of land auctions, buildable area "supplied", and the winning bids in these auctions between purchase restricted and unrestricted districts between the pre- and post-restriction windows. However, in the case of the buildable area allowed, the point estimates suggest a large decline, but the standard errors are also quite large. The point estimates for the number of auctions, though, are quite low in magnitude in addition to being not statistically different from zero, so the buildable area coefficient may be the result of a random composition effect. Overall, developers did not change their bids for land in restricted districts post-policy introduction when compared with unrestricted districts, nor did local governments show any relative difference in the the number of sites brought to auction. This is consistent with no supply response to the purchase restrictions.

The remainder of the paper is structured as follows. In Section 2 we provide a brief summary of Chinese housing policies with a focus on the mix of measures introduced by the Chinese government in 2010 and 2011 with the objective of cooling down Chinese residential real estate markets. This is followed in Section 3 with a review of the literature on policies to 
slow housing markets, covering both macro-prudential regulation and quantity restrictions, both in China and elsewhere. In Section 4, we describe the data used here as well as the identification strategy to test for effects. Finally, in Section 5 we present the results for price and volume effects at different levels of geography along with falsification and placebo tests for robustness. Section 6 concludes.

\section{Chinese Housing Market Interventions}

The introduction of measures to cool the Chinese housing market in 2010 and early 2011 followed a period of intense growth in the Chinese housing market. In the wake of the world financial crisis, China pursued a program of stimulus led by an almost $\$$ US 600 billion investment program announced in Nov 200\&7. Some pointed to this stimulus and the associated increase in liquidity as driving the real estate boom: Wu et al. (2014) estimate real land prices in key Chinese cities rose by a factor of five between 2004 and 2012. Media reports describe high investment flows with investors owning apartments as pure stores of wealth: some estimated up to 30 percent of new apartments being purchased and left vacant 8 . The conditions of rapid price appreciation, surging investment volume, and high rates of new construction following the post crisis stimulus eventually led the Chinese central government to introduce measures intended to rein in the housing market. The State Council issued two directives, the "Ten National Rules" (effective on April 17, 2010) and the "Eight National Rules" (effective on January 26, 2011). These included changes to Housing Provident Fund (HPF) underwriting to raise the minimum LTV with the level determined by unit size and the quantity of units owned $!^{9}$ Minimum down payments on loans from commercial banks were increased by 10 to 20 percentage points, with higher levels for second homes, and in some cases no financing for a third home. Interest rates were also raised, with a minimum allowed rate of 1.1 times the "benchmark rate." Finally, there were steps taken to limit investment in residential real estate directly by restricting the number of properties a person could purchase. While these were directives from the centre, the implementation decision

\footnotetext{
${ }^{7}$ Reported in the New York Times, Nov 9, 2008 "China Unveils Sweeping Plan for Economy", http://www.nytimes.com/2008/11/10/world/asia/10china.html

8 "China's Looming Real-Estate Bubble; A massive Keynesian spending program has misallocated capital and set the stage for a crisis." Wall Street Journal (on-line), Aug. 20, 2010.

${ }^{9}$ The Housing Provident Fund (HPF) is a mandatory savings plan for government, state owned enterprise, and some private business employees. Individual contributions are matched by employers with withdrawals limited to purchase owner-occupied real estate. This is a buyer's lowest cost financing, but the amounts are limited and typically need to be supplemented with bank financing. Studies and summaries of the HPF include Tang and Coulson (2017), Xu (2017), Yang and Chen (2014), Yeung and Howes (2006). An example of the change is that for units greater in size than $90 \mathrm{~m}^{2}$, the minimum down payment required for HPF funds rose from 20 to $30 \%$, and the minimum LTV for a second unit purchased from 40 to $50 \%$.
} 
was left to lower levels of government, where provincial governments forward the messages from the central government to the municipal and lower level governments. It was then up to a local government's discretion to customize these policies and determine the timeline based on local economic conditions.

The implementation of these policies had considerable variation by jurisdiction. First, even the financing policies, which were imposed in all cities varied by implementation date: May 1, 2010 in Beijing to March 31, 2011 in Hefe 10 In contrast to the changes to LTV rules and interest rates, purchase restrictions, which limited purchases based on hukou, a person's official city residency status, were not uniformly imposed. For instance, Guangzhou allowed those with hukou to purchase an additional unit, but forbid any purchases by non-residents; Shanghai allowed both to purchase just one additional unit; and many other cities limited residents to two units and non-residents to one. In addition, not all cities imposed purchase restrictions, and some of those that did so did not impose them uniformly throughout all the districts in the municipality or county. It is the latter group, cities that imposed restrictions on some districts but not on others, that we use for our analysis. We exploit the differences between these groups before and after the imposition of restrictions in a standard differencein-differences (DiD) identification strategy.

For reasons described below in the data section we use data from four cities: Chengdu, Guangzhou, Hefei, and Qingdao. These cities provide us with variation by city type, date of implementation of purchase restrictions, and within city geography. Guangzhou is a Tier 1 city, the others are Tier 2. The municipal governments introduced the policies at different times between October 2010 and March 2011. In all four cities there are at least two districts without quantity restrictions on resident and non-resident buyers. The details, introduction timing, and district allocation of the quantity restriction for each city are provided in Table A-1 in the Appendices.

\section{Literature Review}

The root concern of this paper is the effect of "external" capital flows to real estate. Favilukis et al. (2013) reviewed the literature on country level capital flows and house prices and did not find clear evidence of a relationship in the extant literature at that time. Studies using cross-country panels of capital flows (as measured by the current account deficit) and house prices have been somewhat mixed. Aizenman and Jinjarak (2009) and Sa et al. (2011) find a

\footnotetext{
${ }^{10}$ Our larger sample of cities is limited to 126 of the largest or economically important Chinese cities. These include all major cities and provincial capitals.
} 
positive correlation between the capital account and house price inflation, but Jinjarak and Sheffrin (2011) do not. In contrast, theoretical models of foreign demand (Chao and Yu, 2015; Tai et al., 2017) or non-residents more generally (Favilukis and Van Nieuwerburgh, 2017) demonstrate how these inflows into local housing markets worsen affordability. ${ }^{11}$

Greater success in demonstrating the relationship between capital inflows and house price inflation has come using city level and within city data. Cvijanovic and Spaenjers (2015) study non-resident demand in Paris and find capital inflows concentrate in the most desirable neighbourhoods and affect prices there in particular, but also more generally. Using a panel of UK local authorities, $\mathrm{Sa}(2016)$ links the share of transactions that are registered to overseas corporations to local house price appreciation. Badarinza and Ramadorai (2018) show the effect of country risk driven capital flight on house prices is greater in London neighbourhoods populated by residents of those countries. Using differences across immigrant groups by visa class, Pavlov and Somerville (2017) find that unlike other work, when immigrants come with high net worth, neighbourhood house prices increase faster than in areas with new immigrants more generally.

The most direct antecedent for this paper is the Hilber and Schoni (2016) study of Swiss restrictions on second home purchases. They assess the effects of the January 2013 Swiss "Second Home Initiative" (SHI) that banned the construction of new second homes in Swiss municipalities where these homes made up more than $20 \%$ of the housing stock, which effectively meant construction bans in areas with high resort tourism ${ }^{12}$ They use a difference-in-differences (DiD) methodology, comparing areas where the ban binds compared to those where it does not. They find that the ban resulted in increases in the price of second homes (less future supply) but lowered the prices of primary homes in affected areas by $12 \%$ (negative economic impact). Our paper is somewhat different. First, our constraints occur in urbanized areas, not the tourist areas as in their paper. Second, we obtain our identification from differences within cities, which better controls for the non-randomness of omitted variable problem in DiD estimation. Finally, we are able to study both prices and market activity, rather than just prices alone, and differentiate between demand and supply responses.

Our paper builds more generally on the literature that studies the effectiveness of macro-

${ }^{11} \mathrm{In}$ Chao and $\mathrm{Yu}(2015)$ the welfare implications depend on how taxes on foreign buyers are used, while in Favilukis and Van Nieuwerburgh (2017) the results are sensitive to non-resident versus local preferences for location.

${ }^{12}$ As Hilber and Schoni note, the jurisdictions with more homeowners, more second homes, that are closer to a ski resort were most opposed to the initiative, which had greater support in urban areas with more renters. 
prudential policies in addressing overheating in housing markets ${ }^{13}$ The analysis in this area has tended to use cross country panels (examples include Cerutti et al. (2017) and Zhang and Zoli (2016)), but some work has looked at within country variation, principally Igan and Kang (2011) study of differences across Korea in the intensity of loan to value and debt to income constraints for mortgage lending. These papers find effects of these policies on housing market activity, but less so on prices. The specific type of intervention we study, however, does not operate via the credit channel, but are explicit regulations on the quantity of units that can be purchased by an individual or household. In this we add to a much more limited literature that seeks to measure the effects of these actions. Beyond Hilber and Schoni (2016) this work primarily uses Chinese data because the aforementioned variation in policies and implementation across Chinese cities offers richer identification than crosscountry panels or individual country time series analysis.

While the purchase restrictions introduced in China occurred in tandem with national and local macro-prudential policies, as a non-financial system instrument they are more a direct restraint on demand. In form, they share more in common with policies in other countries that have attempted to reduce non-resident demand through taxation. These purchase restrictions have been the subject of a number of papers. They almost all tend to use a panel of cities and a DiD methodology, comparing cities with and without restrictions, before and after the introduction of the restrictions. The challenge for these papers, is the non-randomness in the application of the treatment, the introduction of restrictions across cities. Those that did are overwhelming the bigger, more economically, faster growing cities in China.

Though not an official hierarchy, Chinese cities are typically broken down into three to four tiers, where the designation reflects a mixture of their economic and political importance ${ }^{14}$ Using YiCai Global's Rising Lab recent 2017 breakdown, which has six tiers, all of the four Tier 1 cities (Beijing, Guangzhou, Shanghai, Shenzhen) had purchase restrictions, as did 13 of 15 Tier $1 \mathrm{~A}$ cities (and the two that did not are outliers in size, Chongqing, or a questionable inclusion, Donguan), 27 of 30 Tier 2 cities had purchase restrictions, and it

\footnotetext{
${ }^{13}$ In contrast to the traditional "micro-prudential" policies, which target individual financial institutions as they experience financial stress, macro-prudential policies combat general equilibrium problems of overall financial system health through policies that affect lending policies, irrespective of the health of individual lender. Hanson et al. (2011), Galati and Moessner (2013), Jordà et al. (2016), and Kahou and Lehard (2017) provide an overview of macro-prudential polices, their effectiveness, and a discussion of the different elements of macro-prudential regulatory tools.

${ }^{14}$ For a discussion of Chinese city tiers see https://www.chinacheckup.com/blogs/articles/china-city-tiers. Rankings are not entirely consistent, for instance comparing YiCai Rising Lab and the South China Morning Post, but consistently the largest 4-5 economies are in Tier 1 and the next group of major economic centres and leading provincial capitals are in the next lower tier.
} 
is only with Tier 3 cities that there are a large number of cities without restrictions (10 of 70 Tier 3 cities had purchase restrictions). Therefore, comparing cities with restrictions to those without mixes differences in political sensitivity, wealth, and economic growth.

A number of the inter-city panels analyses of the restrictions have used different strategies to deal with this identification problem. Cao et al. (2015) apply a DiD methodology to a panel of 70 cities for which they have the National Bureau of Statistics data, of which 39 imposed restrictions. To address the problem of city differences they include pre-trend variables and follow two stage approach of Donald and Lang (2007) to the DiD estimation. They find purchase restrictions associated with a $18 \%$ decline in prices and a $60 \%$ decline in sales volume in the four quarters following the introduction of purchase restriction policies in restricted versus unrestricted cities. Yan and Ouyang (2018) use propensity score matching to define a more limited, but better matching of treatment and control groups to address the problem of unobserved differences across cities. They end up with four cities with restrictions that are matched to four control cities based on per capita GDP and population. Their regressions have limited explanatory power. However, the difference in mean differences appears to be a $20 \%$ relative decline in the prices in restricted cities. Similarly, Du and Zhang (2015) construct a replica of Beijing based on smaller lower status cities that did not adopt purchase restrictions during the period May 2010 and Nov 2011. They compare Beijing price appreciation with its replica and find that price appreciation in Beijing was 7.5 percentage points lower than predicted by the replica after the introduction of the restrictions.

Unlike the inter-city analysis in other papers, Sun et al. (2017), estimate the effects of purchase restrictions in a single city, Beijing. Beijing has a large number of households in the housing market that lack official residency status, so the strict restrictions on non-residents' purchases might be expected to have an acute effect. They use a regression discontinuity design to identify the existence of a structural break associated with the introduction of purchase restrictions on a variety of real estate market variables. They are not able to isolate the effect of purchase restrictions from other policies introduced at the same time, but they find a combined effect of a $23 \%$ decline in house prices post policy constraints. They too find larger effects on volume: a 51-77\% reduction.

Li et al. (2017) use a non-parametric approach that is data driven around the pattern of monthly growth rates in prices. They essentially test for the extent to which price movements immediately following the introduction of purchase restrictions deviates from the overall pattern of price movements. They break their analysis into groups by unit size. While they find some evidence that the restrictions slow housing price appreciation, it is less effective for larger units and for situations where rates of house price appreciation are particularly 
high. 15

The papers cited above rely on a variety of specification techniques to overcome the challenge of non-randomness in the application of restrictions. Methodologically, the contribution of this paper is that we use detailed data that provide housing market measures at the project level. This allows us to take advantage of the differences in the imposition of purchase restrictions within cities. We argue that because the treatment and non-treatment areas share the same general housing and labour markets and are the same local economy. We have treatment and control groups (different districts within a single city) that are much more similar in conditions than is the case in the existing research.

The second part of our paper is an analysis of the effects of the restrictions on land sales by local governments to developers. This provides us with an indirect method to assess the effects of the restrictions on the supply function. We know of no other analyses of these types of restrictions on investor demand for residential real estate that address supply-side factors.

\section{Data and Identification}

\subsection{Data}

The data used in the analysis are from the Chinese Real Estate Index System (CREIS). CREIS records housing transaction data in China from information published by the central, provincial and local governments on a weekly or monthly basis. Transactions data are reported at the city, project, and deeds levels, where the first two are aggregate data and the last are individual transactions. We use monthly project level aggregate data from CREIS. The data cover 49,525 projects in 126 cities from as early as 2005. However, we are interested in the variation in purchase restrictions within a city by district limits, which limits us to nine of the cities in these data. And of these nine cities, we have sufficient pre-2011 data for only four of them as prior to 2011 the CREIS data is very sparse, with no observations for most cities, especially for the deeds data. We are left with data of 2,014 projects in Chengdu, Guangzhou, Hefei, and Qingdao. Though we have fewer cities in the data, the key advantage of using within city variation is that it reduces the scope of the treatment from across very

\footnotetext{
${ }^{15}$ There is also a literature in Chinese academic journals that studies the policies that we test. Liu (2013) and Wang and Huang (2014) establish different equilibrium models to gauge the effect of the purchase restriction policy. Liu (2013) states that the direction of the housing price movement is unclear given the different conditions. Wang and Huang (2014) suggest that the purchase quota policy may reduce housing prices, but at an insignificant magnitude.
} 
different cities to within cities. Still, it does not fully solve the randomness problem as in the cities in our sample core urban districts have restrictions while more suburban ones do not. As we describe below we take steps to address these differences and validate our findings.

The particular observations dates we use vary by city because the purchase restrictions were introduced on different dates in the four cities. Guangzhou introduced policies on October 15, 2010; Qingdao on January 31, 2011; policies were implemented in Chengdu on February 15, 2011; and on March 31, 2011 in Hefei. For project transaction volumes, we have observations from Oct 2009 on for all districts, but only from six months prior to the restriction introduction for prices. We drop October 2010 for Guangzhou and February 2010 for Chengdu from the data because the policies were implemented mid-month and we only have monthly aggregations. In the basic set of regressions we will use a six month pre-restriction window (before) and then either six or twelve month post-restriction window (after).

Following the directives from the central government, these municipalities imposed restrictions on the more central and core urban districts. Buyers of properties in more distant suburban districts were not subject to the purchase restrictions. Figure 1 shows the distribution of projects across city districts for the four cities, differentiating between purchase restricted and unrestricted districts. In contrast, the changes in housing finance rules, both higher interest rates, down payment requirements, and limits on HPF loans applied in all areas.

\section{[Figure 1 Inserted Here]}

In the data, each observation is a project's summary statistics for a given month. Of these, we we use the average unit price (Chinese Yuan per square meter $\left(m^{2}\right)$ ), total units sold in the project that month, and average unit size $\left.\left(m^{2}\right)\right)$. We provide these summary statistics for the project aggregates in the four cities in Table 1 for the -6 month $/+12$ month window. The data are broken down between purchase restricted and unrestricted districts, and for periods before and after the imposition of the restrictions. mean monthly sales volumes per project are lower in the core-area restricted districts than in the unrestricted districts. Consistent with urban models, prices are higher and average unit sizes are lower in more central restricted districts than in the unrestricted suburban districts both before and after the implementation of restrictions. Unit prices rise in both types of districts after the imposition of purchase restrictions, and sales volumes fall in both district types. The latter finding is consistent with the a decline in demand following the introduction of lending restrictions, higher interest rates, and higher down payment requirements that affect 
all districts in these cities and were introduced at approximately the same time. However, the rise in prices over the period is not consistent with that explanation. We provide similar descriptive statistics by city in Appendix Table A-2. The patterns in each city are similar to those in the aggregate data shown in Table 1 .

\section{[Table 1 Inserted Here]}

CREIS also complies land transaction information in China from information published by the central, provincial, and local governments on individual land auctions. The dataset includes detailed land characteristics, such as transaction price, transaction date, listing date, reserve price of an auction, size and location of land parcel, maximum building area per unit of land or floor space ratio (FSR), land type (residential, commercial, industrial, mixed, and others), transaction type (negotiation [xieyi], English auction[paimai], two-stage auction [guapai], and sealed bid auction[zhaobiao]), and buyer name (both firm and individual). We limit the data to residential land sales in the four cites used above. The summary statistics for Chengdu, Guangzhou, Hefei, and Qingdao for price and quantity measures are reported in Table 2. As with unit sales, land prices are higher in the core restricted districts and prices rise in both regions over the period. Average land area and buildable area per land auction are lower in both regions post-restrictions. After is twelve months and before is six months, so the number of auctions does decline in both areas. These are broken down by city in Appendix Table A-3.

\section{[Table 2 Inserted Here]}

\subsection{Specification}

If the Chinese government interventions were successful, then we would expect to see both a decline in transaction volume as investors reduced purchases, and a decline in prices in response to the rightward shift in demand. We hope to exploit within market differences, where the restrictions in some areas result in a drop in demand in those areas, when compared with areas in the city that did not restrict demand. Between the pre- and post-restriction periods, the areas with restriction should have relative declines in both prices and volumes. The price effect, though depends, on the extent of downward price rigidity. In particular, if developers are not under pressure from lenders to liquidate unsold properties, and they believe that restrictions are temporary, it may be more profitable to not reduce prices and wait out the decline in demand.

We use two different regression specifications for the DiD analysis. The first is the 
standard treatment where we have a dummy variable After that takes on the value of one in the months after the introduction of purchase restrictions. Projects in districts where purchase restrictions are or will be imposed have the value of one for the dummy variable Treat $_{i}$. The DiD effect is captured in the interaction of these two in Treat $_{i} *$ After $_{t}$. Formally:

$$
y_{i, t}=\alpha+\beta_{1} * \text { Treat }_{i} * \text { After }_{t}+\beta_{2} * \text { After }_{t}+\beta_{3} * X_{i, t}+\mu_{i}+\delta_{t}+\epsilon_{i, t}
$$

where $y_{i, t}$ is one of the outcome variables (price or transactions) for project $i$ in year-month $t$. $X_{i, t}$ are other time and project specific control variables. $\mu_{i}$ refers to the project fixed effects, capturing the unobserved mean variations across projects. $\delta_{t}$ is the set of year-month fixed effects. The estimated coefficient of interest for the DiD effect is $\beta_{1}$. The dummy variable Treat $_{i}$ does not enter on its own because it is subsumed in the project fixed effects $\mu_{i}$. Policy implementation dates vary, so After $_{t}$ is not perfectly co-linear with the year-month fixed effects $\delta_{t}$.

We use two alternative specifications. Both address the effects the innate differences between the treatment and non-treatment districts might have on the DiD coefficients of interest in ways not covered by Specification (1), which assumes no systematic time-varying pre-treatment differences.

The first allows for non-parallel trends in the data in the period prior to the treatment (introduction of restrictions). We do by allowing the the pre-treatment (months before purchase restrictions were applied) mean effect for the projects in districts where there will be restrictions to vary from that of the non-treatment districts. Formally, we interact Treat $_{i}$ (the treatment fixed effect) with Before $t_{t}^{\prime \prime}$, which has the value of one for the second three months of the six month pre-restriction period and zero otherwise. Other elements are similar to specification (1):

$$
\begin{array}{r}
y_{i, t}=\alpha+\beta_{1} * \text { Treat }_{i} * \text { Before }_{t}^{\prime \prime}+\beta_{2} * \text { Treat }_{i} * \text { After }_{t}+\beta_{3} * \text { After }_{t}+ \\
\beta_{4} * X_{i, t}+\mu_{i}+\delta_{t}+\epsilon_{i, t}
\end{array}
$$

Here $\beta_{1}$ will show the sign and statistical significance of a pre-treatment trend difference for projects in districts with purchase restrictions that would cause specification (1) to violate the no parallel trends assumption. The estimated coefficient of interest for the DiD effect is $\beta_{2}$. The magnitude of the difference is the difference between $\beta_{2}$ and $\beta_{1}$. 
The second alternative imposes more functional form for trend differences in the dependent variable before and after the introduction in restrictions across the two groups of districts. Here we allow for different trends between the restricted and non-restricted areas, through Trend and Treat $*$ Trend, and then the difference in differences above and beyond this through a third interaction Treat $*$ Trend $*$ After. The full specification is:

$$
\begin{array}{r}
y_{i, t}=\alpha+\beta_{1} * \text { Trend }_{+} \beta_{2} * \text { Treat }_{i} * \text { Trend }+\beta_{3} * \text { Treat }_{i} * \text { Trend }_{\text {Tfter }}+ \\
\beta_{4} * \text { After }_{t}+\beta_{5} * X_{i, t}+\mu_{i}+\lambda_{\text {month }}+\epsilon_{i, t}
\end{array}
$$

The variables have the same meaning as noted above except that $\lambda_{\text {month }}$ is a month fixed effect for seasonality. The sign of the DiD effect is captured by $\beta_{3}$ There is not a simple parameter or combinations of parameters to identify the magnitude of the effects of the restrictions because they depends the values for Trend. We will estimate the changes for each of the windows using the mid-trend value for each before and after window period. As with the two previous specifications stand alone values for Treat are subsumed in the project fixed effects.

\section{Results}

\section{$5.1 \quad$ Apartment Sales}

These empirical estimates of the relative effect of purchase restrictions use monthly residential development project level data for prices and sales volumes of apartment unit sales by month. In Table 3, we test the difference in individual development project mean log apartment prices per $\mathrm{m}^{2}$ of floor area across districts before and after the introduction of purchase restrictions. All else being equal, one would expect higher demand in unrestricted areas as investors shifted their purchases their from districts where they were constrained on how many apartments they could buy. If the restrictions diverted demand from one region to the other, then with any inelasticity in supply we would expect to see prices rise in the unrestricted areas relative to the districts with purchase restrictions.

All regressions in Table 3 use a six-month pre-treatment window, which varies slightly by city ${ }^{16}$ The first three regressions use a six-month post-purchase restriction policy imple-

\footnotetext{
${ }^{16}$ Purchase restriction introduction dates are: October 15, 2010 for Guangzhou, January 31 , 2011 for Qingdao, February 15, 2011 for Chengdu, and March 31, 2011 for Hefei. We drop the October 2010 observation for Guangzhou and the February 2011 observation for Chengdu to keep clean pre- and post-restriction
} 
mentation after window; the second three use a twelve-month post window. Within each window length group, the regressions are ordered by specification. We follow this presentation structure in subsequent tables, though the post window lengths do vary for some tables.

The DiD effect for specifications (1) and (2) is the coefficient on Treat * After. For specification (3) it is the estimated coefficient on Treat $*$ Trend $*$ After. The calculation of the magnitude of the effects varies by specification. For specification (1) it is the estimated coefficient on Treat $_{i} *$ After $_{t}$; for specification (2) the difference between Treat $_{i} *$ After $_{t}$ and Treat $_{i} *$ Before $_{t}^{\prime \prime}$; and for specification (3) specific trend start and end values applied to the benchmark pre- and post-periods and then multiplied by $\operatorname{Trend}_{t}$, Treat $_{i} * \operatorname{Trend}_{\text {) }}$, and Treat $_{i} *$ Trend $_{)} t *$ After $_{t}{ }^{17}$. There is no statistically significant difference in the change in prices post-restriction implementation date between development projects in regions with purchase restrictions and those without. The effects are also small in magnitude, ranging from 1.0 to $3.4 \%$ across specifications.

\section{[Table 3 Inserted Here]}

There remains the possibility that prices are just slow to adjust. In Table 4 we extend the post-restriction introduction windows to eighteen and twenty four month post windows. Here too the effects are all statistically not different from zero, with standard errors larger than the point estimates on the relevant variables. The estimates are also extremely small in magnitude. In the absence of perfectly elastic supply, this suggests either no difference in demand, or strongly downward sticky prices in the restricted districts.

\section{[Table 4 Inserted Here]}

In contrast to the effect on prices, there are qualitatively large and statistically different from zero effects of the purchase restrictions on differences in transaction volumes across the two types of districts. Table 5 shows transaction volumes drop off much more after the introduction of restrictions in projects in the districts with purchase restrictions than in those without: falling by $42-51 \%$ in the six month window. As the analysis window lengthens, the size of the effect declines, to a 30-36\% decline for the twelve month window. These changes are statistically different from zero across all three specifications. Table 6 shows the results for longer windows, where the effects are lower still. Though the price regressions did not suggest a differential effect from the presence of restrictions, the effect is very strong and

introduction date sub-samples.

${ }^{17}$ We use window mid-point trend values, where Trend $=1$ for Oct 2008 . For +6 month the values are 25 and 31; for +/- 12 months they are 25 and 37. Strictly we calculate the trend effect pre and post for both groups and take the difference in the differences. 
clear on the volume of property purchases. This suggests that the absence of a price effect is likely because of downward sticky prices or a significant inward shift in supply, given the statistically significant and meaningful relative decline in transaction volume in the restricted districts.

\section{[Table 5 Inserted Here]}

\section{[Table 6 Inserted Here]}

To test for robustness beyond different specifications, we conduct border discontinuity regressions using the DiD methodology. Here we limit the sample to projects within $3 \mathrm{~km}$ of the border between districts where purchase restrictions are imposed and those where they are not. While the districts are different, this should reduce the variation in unobserved location characteristics between projects in the restricted vs. unrestricted districts by excluding those that are particularly close (in the restricted districts) or far away (in the unrestricted districts) from the urban centre. The effect of limiting the analysis to projects on the border is that we should exclude the highest priced, most desirable, core urban areas, and least expensive, least desirable suburban districts, which we assume are most likely to be fundamentally different, from the analysis. We show the included areas and projects on either side of the border in Figure 3. Descriptive statistics mimicking those in Table 1 for

projects in the $3 \mathrm{~km}$ band on either side of the border are shown in Appendix Table A-4, where we see a similar pattern to the district-wide statistics in Table 1 .

\section{[Figure 3 Inserted Here]}

In Tables 7 and 8 we present the same regressions as those shown in Tables 3 and 5 but using the more focused border discontinuity sample. The differences between the border and entire district samples vary slightly by specification, but the patterns and general magnitudes are consistent across both samples. The overall results for prices are again qualitatively small and not statistically different from zero. For decreases in transactions between the restriction and non-restriction districts we get large and statistically different from zero declines in relative transaction volume in the restricted zone. The six month window effects are a bit larger than in the district analysis, with declines all approximately $48-51 \%$ across specifications, falling to declines of $31-37 \%$ for the twelve month windows. Longer windows yield consistent results with smaller aggregate declines in volume with window length, as with the district regressions above.

\section{[Table 7 Inserted Here]}




\section{[Table 8 Inserted Here]}

In all these regressions using specification (2), for both prices and volumes, we regularly reject a unique pre-trend for districts where subsequently the municipal government will impose purchase restrictions. The coefficient $\beta_{4}$ on Treat $_{i} *$ Before $_{t}^{\prime}$ identifies the percentage mean difference between prices or transaction volumes for projects in the districts that have purchase restrictions imposed 3-6 months vs. 0-3 months prior to the restriction implementation. This estimated coefficient is never statistically different from zero and is typically small in magnitude. As a result, in subsequent apartment sales tables we will just present specification (1), for the land sales data we will re-test these three specifications.

\subsection{Falsification Tests}

To test for possible spurious results in either geography or time, we conduct two falsification tests. The first is a border discontinuity DiD placebo test where we create an artificial district boundary within districts without purchase restrictions. This addresses whether the difference we see in the $\mathrm{DiD}$ regressions above reflects purchase restrictions or just a more general effect related to distance from the city centre, since the purchase restricted areas are closest to the urban core. For instance, the higher down payment requirements from the macro-prudential policies introduced during the same time period as the purchase restrictions could depress demand more for higher priced properties, which are more likely to be located in purchase restriction, urban core areas. If price falls continuously with distance, then this would show up again in this placebo test. The second placebo test examines whether the DiD effects above just reflects more general time patterns, either as part of the real estate cycle or resulting from the broader macro-prudential restrictions on housing finance, that affected districts deferentially. We proxy the introduction of the purchase restrictions as occurring separately as prior and subsequent to when they actually occurred, and have both pre- and post- periods lie entirely in the period either prior or post to the actual introduction of restrictions.

The geographic tests create a placebo purchase restriction and $3 \mathrm{~km}$ band in districts that do not actually have restrictions. One half of this band lies $0-3 \mathrm{~km}$ from the border with the actual purchase restriction districts but is entirely in non-restricted districts. This is compared with the second half of the band that lies $3-6 \mathrm{~km}$ from the border. The falsification test is that demand fell more for more expensive areas, as defined by proximity to, so we assign the placebo treatment effect to the $0-3 \mathrm{~km}$ band area, which is closer to the city centre. Table 9 show the results of this geographic falsification test for specification (1). There is 
no statistically significant difference in the changes in prices or transaction volume between the two areas pre-and post-restriction dates. As well, the point estimates are small. This is consistent with the results we present above being because of the difference in restrictions across districts and not differences in proximity to the city centre.

\section{[Table 9 Inserted Here]}

The time falsification tests are presented in Table 10 again just using specification (1). Because of limited price data more than six months prior to the restriction imposition dates we are constrained to testing transaction volumes alone. However, we only obtained statistically different from zero results for volume. Regressions (1) and (2) have a placebo restriction assigned to a period prior to the actual restrictions: 0-6 months prior for regression (1) and 0-10 months for regression (2), where both pre-and post-restriction periods occur before the actual introduction of restriction. For regressions (3)-(5) both periods occur after the actual introduction, so the placebo is assigning a no-treatment where one actually existed. Within these groups, the regressions differ by window length. The results are consistent: the estimated coefficient on the interaction Treat $_{i} *$ After $_{t}$ is consistently not statistically different from zero. Hence, no differences in transaction volumes over the period between the placebo and time period correct samples.

\section{[Table 10 Inserted Here]}

\subsection{Land Supply - Government Auctions}

The analysis in the previous section evaluates the outcomes in the market for completed apartment (condominium) units. We cannot necessarily distinguish what part of the identified changes comes from the effect on investor demand because of purchase restrictions, and what may come from a supply response. For instance, the observed drop in volume without a decline in prices is consistent with a shift inwards in both demand and supply curves. It is also consistent with a drop in demand but no drop in developer reservation price, because the profit maximizing strategy is to wait until the policies are reversed rather than sell at a discount.

To shed light on supply side effects, we perform the same DiD tests on the land supply market. In Chinese cities, local governments determine land supply through the auction of lands they designate as available to developers, which is an important source of local 
government revenue. With these auctions, the short-run quantity effects should reflect local governments' decisions to bring land to the market, while price effects are determined by the bids of developers, given the current and expected future supply of land and expected conditions in the apartment market when they expect to sell units developed on the land up for auction. Thus, we interpret the quantity effects, number of land auctions and total buildable area, as reflecting government land supply, and the price effects developer demand given this supply ${ }^{18}$ No decline in land supply, but a decline in prices suggests that there is an inward shift in developer supply. But if land auction bids do not decline, that is more consistent with the developers waiting out the policy without lower prices.

Estimates of the differential effect of purchase restrictions on the price bid for land in restricted and unrestricted districts rice effects in the land auctions are shown in Table 11. The dependent variable is the log of price paid for land per buildable $m^{2}$, the land component of potential buildable area. The coefficients on the DiD measures are not statistically different from zero, rejecting the hypothesis that land auction prices changed deferentially in response to the variation in purchase restriction on apartment buyers. The point estimates suggest a moderate decline of between 2 and 11\%, but the standard errors are quite large to have any confidence in these magnitudes or price direction. The results imply that given the supply of land for development, developers did not lower their bids more, or raise them less, in the districts with restrictions. This has two possible explanations, either the supply of auctions dropped enough to keep prices stable or developers were confident that there would not be a major long term effect on profitability from the purchase restrictions, as land bids reflect sales of units at least two years further on in the development process.

\section{[Table 11 Inserted Here]}

To test for land supply effects by local governments we test two different measures of quantity in land supply. The first is the number of land auctions that occurred, the second is the total buildable area that could result from development on the auctioned land. The number of auctions are aggregate counts per district-month, the totals in a district in a given month, so our observation count is much lower than in the other analyses here. For buildable area per auction we use individual land auctions as the unit of observation and are assessing the variation over time and across districts in the amount of buildable area offered in any given land auction. Table 12 shows the relative change in the number of land auctions between restricted and unrestricted districts over the period before and after the implementation of the purchase restrictions. There is no apparent change, the raw

\footnotetext{
${ }^{18}$ Total potential supply of apartment space in the auctioned land is calculated as the total auction land area times the maximum allowed floor space ratio (FSR), which is the built area to land area ratio used in land use regulations.
} 
magnitudes of the point estimates are all below a $4 \%$ change and the standard errors are large relative to the point estimates. Table 13 presents the building area regressions. Here too, we cannot reject that buildable area per auction did not decline in restricted areas, compared with non-restricted areas, following the restrictions. However, the point estimates of declines are large in magnitude, though offset by the very sizable standard errors. 19

\section{[Table 12 Inserted Here]}

\section{[Table 13 Inserted Here]}

The land supply regressions do not indicate a inward shift in supply in response to the purchase restrictions. Land prices, the number of parcels auctioned, and the buildable potential did not change in any differential way between districts with restrictions and those without. This pattern is consistent with developers who see the government policies as temporary, to be reversed after some period. As a result, with no drop in the offered land in restricted areas compared to unrestricted areas they did not have differential changes in bids. Such a response is also consistent with prices of their completed units remaining unchanged in the face of less buyer demand.

\section{Conclusion}

In this paper, we look at the effects of restrictions on investor purchases of residential properties on housing market outcomes. These restrictions were introduced in China, and elsewhere more typically as differential taxes, to try to calm overheated housing markets address worsening affordability. Here we try to measure the effectiveness of the Chinese policies at achieving these objectives. While others have studied China's restrictions policy, they have relied on cross-city panels using a methodology that assumes policy treatment is random. Where we differ is that we exploit variation in the implementation of these policies within cities, which represents a step forward towards a cleaner test. While we do not fully escape the non-randomness problem, because restrictions are imposed in central districts and not in suburban districts, our results are consistent with both robustness and falsification tests. Additionally, we use data from government land auctions to compare outcome sin the end-user apartment market with conditions in the land input market. These comparisons indicate that our observed results come from the shift in demand by apartment purchasers and not be changes in developer or government land seller actions.

\footnotetext{
${ }^{19}$ Falsification tests like those applied to the project data and presented in Tables 9 and 10 do not yield any statistically different from zero results.
} 
Uniformly we find that districts within a city where there were restrictions on purchases of apartments had significantly greater declines in transaction volume than did districts without these restrictions following their introduction. At the same time, there were no differential changes in transaction prices. The declines ere large, in excess of $40 \%$ in the first six months following the implementation of restrictions, but this declined to less than $30 \%$ after twelve months. The supply regressions also show no differential decline in land bids and or in the number of land auctions over this period across the restricted and unrestricted districts of the four cities we study. Together this suggests that while buyers were affected by the restrictions, developers did not drop prices and behaved in a manner consistent with an expectation that the restrictions were temporary and waiting to sell was more profitable than dropping prices.

Using our within-city sample we get different results than researchers who have studied these restrictions across cities. Our decline in volumes is at least 10 percentage points lower, and most striking, while they find price declines in cities with restrictions of up to $16 \%$ compared to those without, we find find no differential change in prices across districts. While the difference in differences methodology this is particularly not well suited to explain aggregate changes, this is especially true for this period in China when macro-prudential policies that limited mortgage borrowing were also imposed across all principal cities.

The stated objective of the restrictive policies was to tame high and accelerating house prices and calm markets. We find little evidence on reversing housing price inflation, though market activity clearly declined. In this, the purchase restrictions are both consistent with the contention that housing markets clear in both volume and prices, not just prices (Clayton et al. 2010; Stein, 1995), but importantly with the research on macro-prudential policies tghat finds that these too can have strong dampening effects on market activity but their ability to reverse problems of high house prices and address affordability are limited at best. 


\section{References}

Aizenman, J. and Y. Jinjarak (2009). Current account patterns and national real estate markets. Journal of Urban Economics 66(2), 1-13.

Badarinza, C. and T. Ramadorai (2018). Home away from home? foreign demand and london house prices. Journal of Financial Economics On-line https://doi.org/10.1016/j.jfineco.2018.0\%.010.

Cao, J., B. Huang, and R. N. Lai (2015). On the effectiveness of housing purchase restriction policy in china: a difference in difference approach. Working Paper.

Cerutti, E., S. Claessens, and L. Laeven (2017). The use and effectiveness of macroprudential policies: New evidence. Journal of Financial Stability 28, 203-224.

Chao, C.-C. and E. S. Yu (2015). Housing markets with foreign buyers. The Journal of Real Estate Finance and Economics 52(2), 207-218.

Clayton, J., N. Miller, and L. Peng (2010). Price-volume correlation in the housing market: causality and co-movements. The Journal of Real Estate Finance and Economics 40(1), 14-40.

Cvijanovic, D. and C. Spaenjers (2015). Real estate as a luxury good: Non-resident demand and property prices in paris.

Donald, S. G. and K. Lang (2007). Inference with difference-in-differences and other panel data. The Review of Economics and Statistics 89(2), 221-233.

$\mathrm{Du}$, Z. and L. Zhang (2015). Home-purchase restriction, property tax and housing price in china: A counterfactual analysis. Journal of Econometrics 188(2), 558-568.

Favilukis, J. Y., D. Kohn, S. C. Ludvigson, and S. Van Nieuwerburgh (2013). International capital flows and house prices: Theory and evidence. Housing and the Financial Crisis, 235-299.

Favilukis, J. Y. and S. Van Nieuwerburgh (2017). Out-of-town home buyers and city welfare.

Galati, G. and R. Moessner (2013). Macroprudential policy-a literature review. Journal of Economic Surveys 27(5), 846-878.

Hanson, S. G., A. K. Kashyap, and J. C. Stein (2011). A macroprudential approach to financial regulation. Journal of Economic Perspectives 25(1), 3-28.

Hilber, C. A. and O. Schoni (2016). The housing market impacts of constraining second home investments. Igan, D. and H. Kang (2011). Do loan-to-value and debt-to-income limits work? evidence from korea.

Jinjarak, Y. and S. M. Sheffrin (2011). Current account patterns and national real estate markets. Journal of Macroeconomics 33(2), 233-246.

Jordà, Ò., M. Schularick, and A. M. Taylor (2016). The great mortgaging: housing finance, crises and business cycles. Economic Policy 31(85), 107-152.

Kahou, M. E. and A. Lehard (2017). Macroprudential policy-a literature review. Journal of Financial Stability 29(1), 92-105.

Li, V. J., A. W. W. Cheng, and T. S. Cheong (2017). Home purchase restriction and housing price: A distribution dynamics analysis. Regional Science and Urban Economics 67, 1-10.

Liu, L. (2013). Impact of credit rationing and quantity limit on housing price. Journal of Management Sciences in China 9.

Pavlov, A. and T. Somerville (2017). Immigration, capitral flows, and house prices.

Sa, F. (2016). The effect of foreign investors on local housing markets: Evidence from the uk.

Sa, F., P. Towbin, and T. Wieladek (2011). Capital inflows, financial structure and the housing booms. Journal of the European Economic Association 12(2), 522-546. 
Stein, J. C. (1995). Prices and trading volume in the housing market: A model with down-payment effects. The Quarterly Journal of Economics 110(2), 379-406.

Sun, W., S. Zheng, D. M. Geltner, and R. Wang (2017). The housing market effects of local home purchase restrictions: evidence from beijing. The Journal of Real Estate Finance and Economics 55(3), 288-312.

Tai, M.-Y., S.-W. Hu, C.-C. Chao, and V. Wang (2017). The impact of china's housing provident fund on homeownership, housing consumption and housing investment. International Review of Economics and Finance 52(2), 368-379.

Tang, M. and N. E. Coulson (2017). The impact of china's housing provident fund on homeownership, housing consumption and housing investment. Regional Science and Urban Economics 63, 25-37.

Wang, M. and Y. Huang (2014). Can house purchase quota policy and property tax reduce the housing price? a long run dynamic equilibrium analysis of housing market. The Journal of World Economy in China, 141-159.

Wu, J., Y. Deng, and H. Liu (2014). House price index construction in the nascent housing market: The case of china. The Journal of Real Estate Finance and Economics 48(3), 522-545.

$\mathrm{Xu}, \mathrm{Y} .(2017)$. Mandatory savings, credit access and home ownership: The case of the housing provident fund. Urban Studies 54(15), 3446-3463.

Yan, Y. and H. Ouyang (2018). Effects of house-sale restrictions in china: a difference-in-difference approach. Applied Economics Letters 25(15), 1051-1057.

Yang, Z. and J. Chen (2014). Housing reform and the housing market in urban china. In Housing Affordability and Housing Policy in Urban China, pp. 15-43. Springer.

Yeung, S. C. and R. Howes (2006). The role of the housing provident fund in financing affordable housing development in china. Habitat International 30(2), 343-356.

Zhang, L. and E. Zoli (2016). Leaning against the wind: Macroprudential policy in asia. Journal of Asian Economics 42, 33-52. 
Figure 1: Purchase Restriction by District and Geographic Distribution of Housing Projects

Purchase Restriction by Districts and Housing Projects in Chengdu

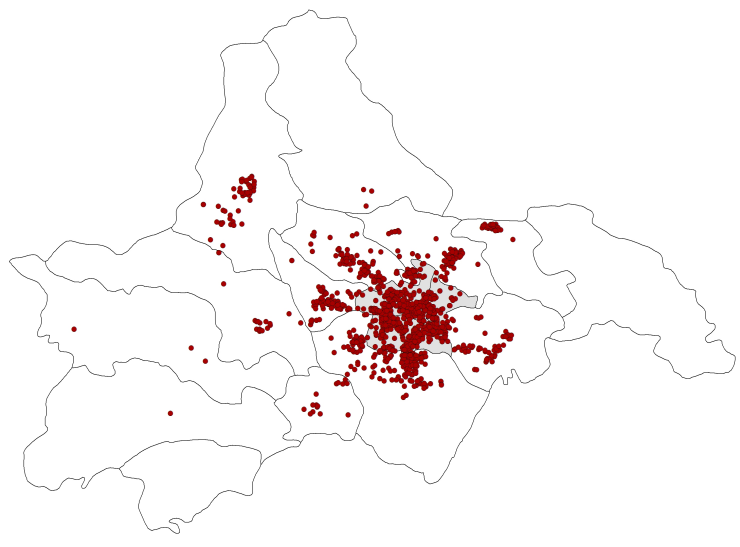

$\underset{\text { Legend }}{\stackrel{\text { Housing Project }}{ }}$

$\square$ Chengdu-District Boundary

$\square$ Disctricts with the Purchese Restriction

Purchase Restriction by Districts and Housing Projects in Hefei

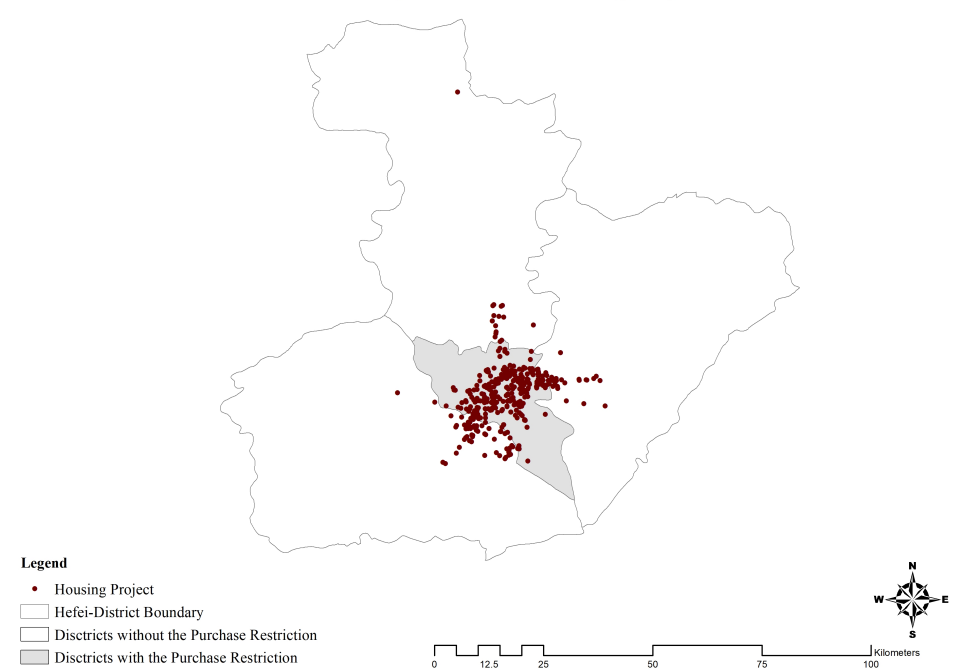

Purchase Restriction by Districts and Housing Projects in Guangzhou

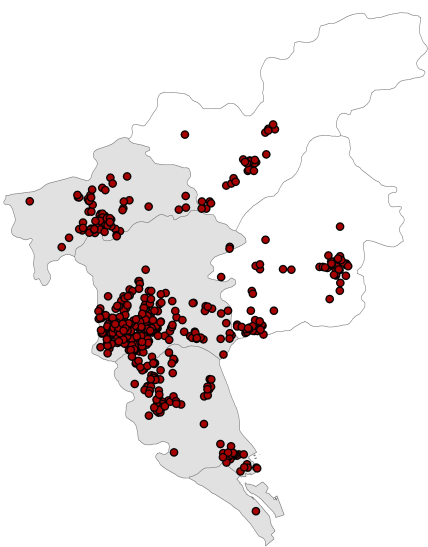

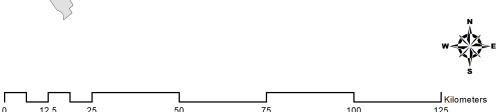

Purchase Restriction by Districts and Housing Projects in Qingdao
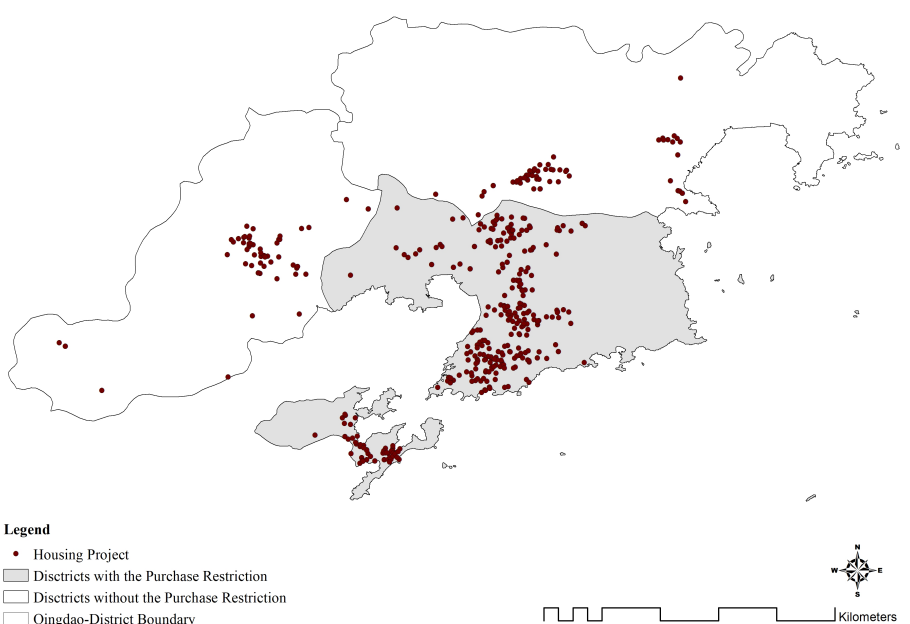

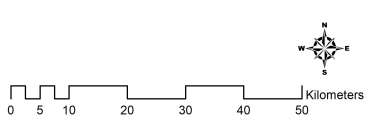

Notes: This figure presents the the geographical distribution of housing projects across city districts for the four cities. The areas of shaded regions correspond to the districts subject to the purchase restrictions. The dots in red represent the housing projects. 
Figure 2: Purchase Restriction by District and Geographic Distribution of Transacted Land Parcels

Purchase Restriction by Districts and Land Transactions in Chengdu
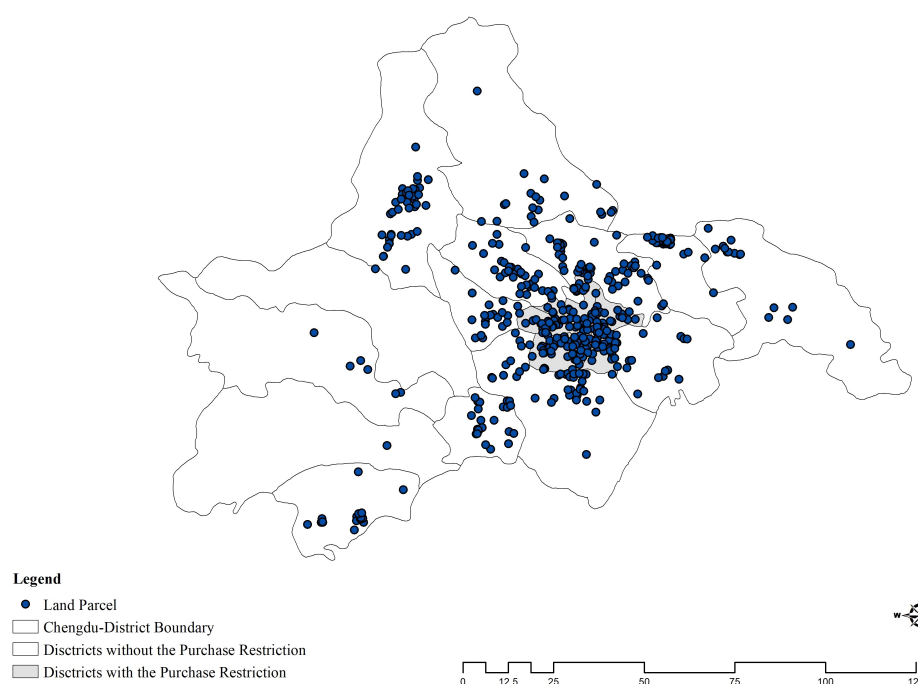
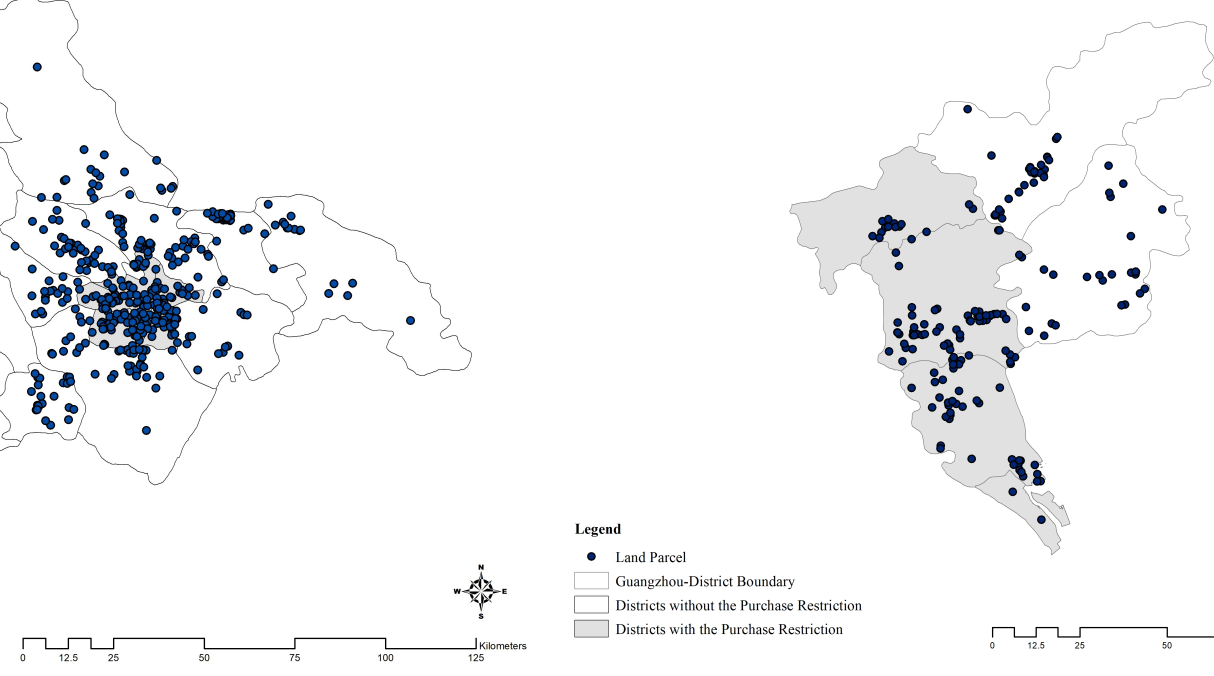

Purchase Restriction by Districts and Land Transactions in Hefei

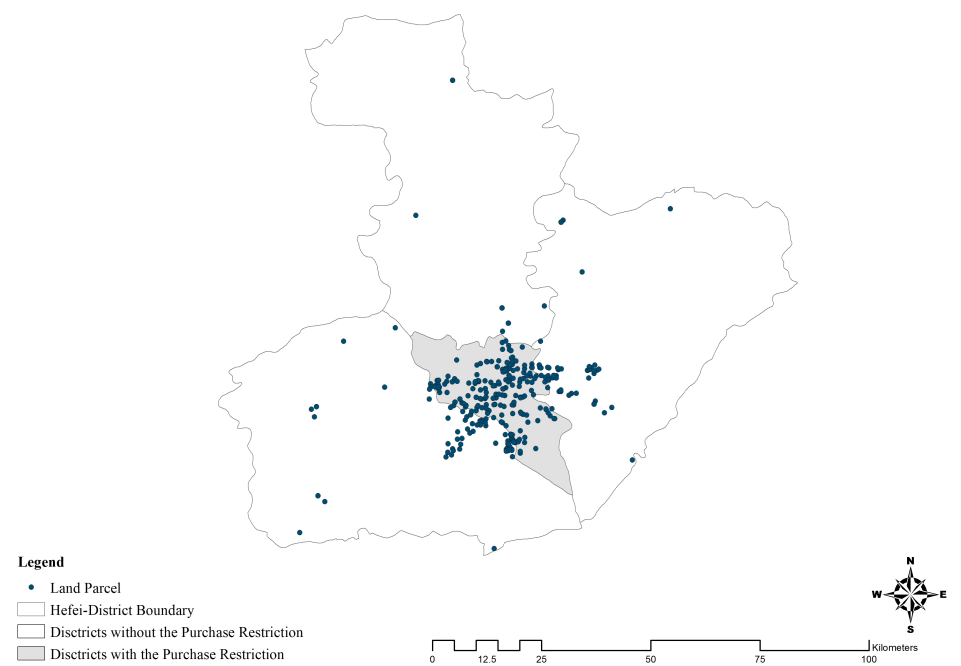

Purchase Restriction by Districts and Land Transactions in Qingdao
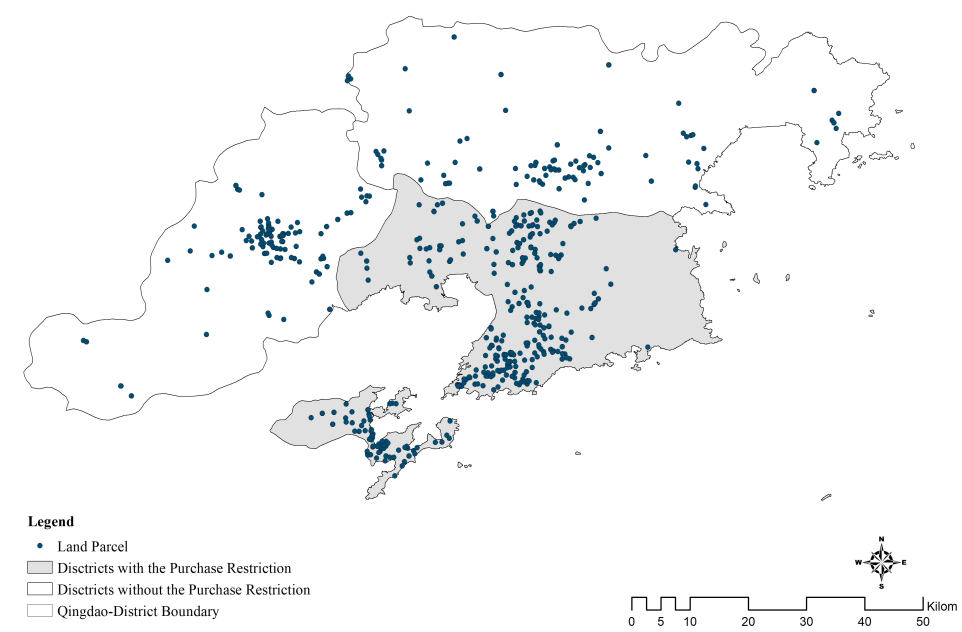

Notes: This figure presents the the geographical distribution of transacted land parcels across city districts for the four cities. The areas of shaded regions correspond to the districts subject to the purchase restrictions. The dots in navy represent the housing projects. 
Figure 3: 3 KM Border Analysis and Geographic Distribution of Housing Projects

3 KM Border Analysis and Housing Projects in Chengdu

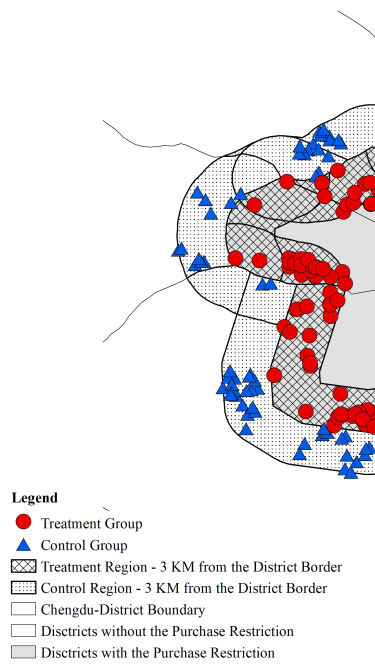

3 KM Border Analysis and Housing Projects in Hefei

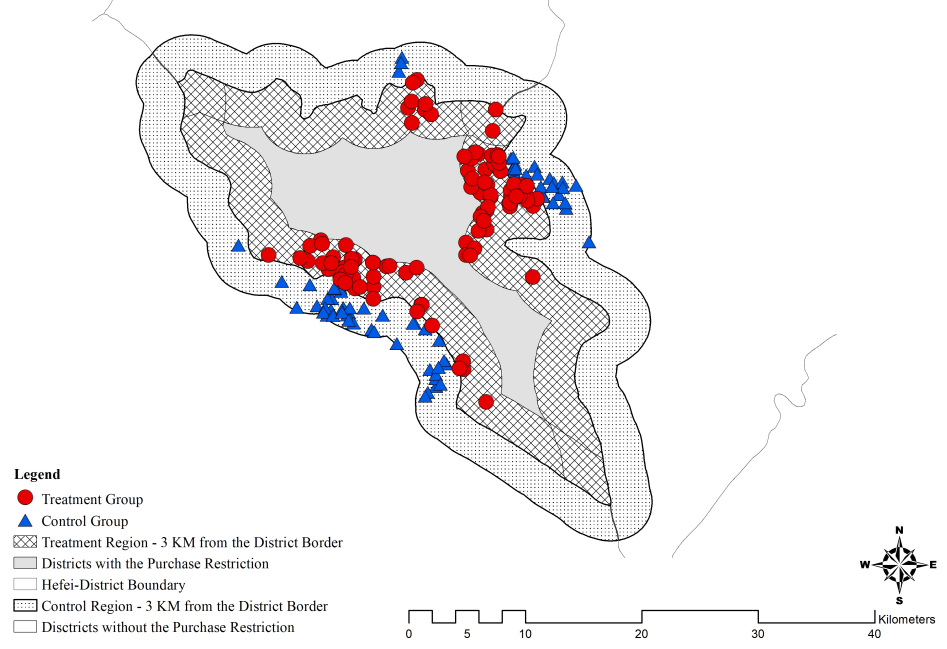

3 KM Border Analysis and Housing Projects in Guangzhou

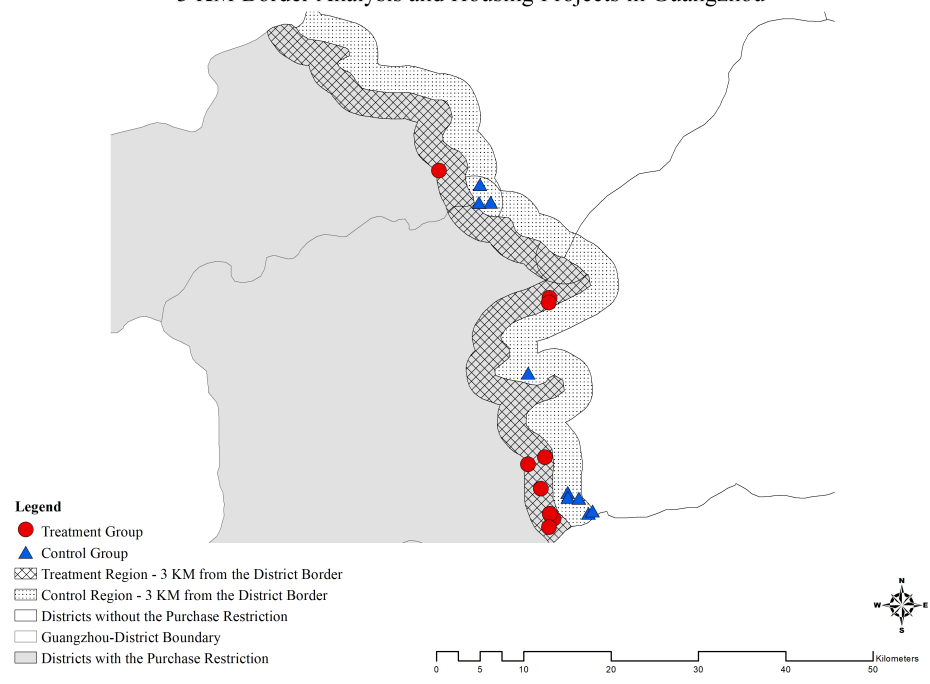

3 KM Border Analysis and Housing Projects in Qingdao

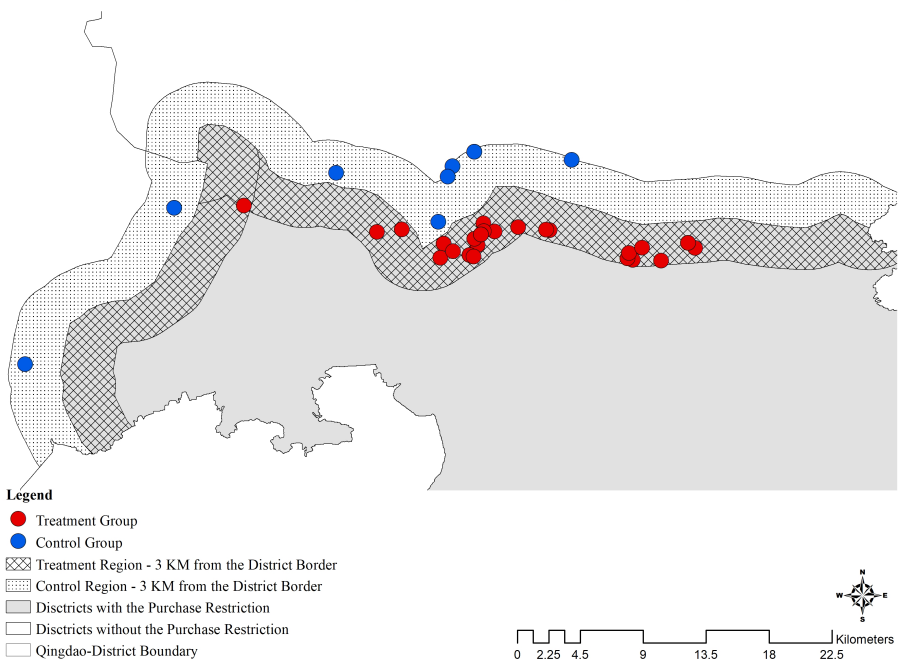

Notes: This figure shows the geographic distribution of housing projects within $3 \mathrm{~km}$ of the border between districts with and without the restrictions in each city. The dots in red denote housing projects located in the restricted districts and the triangles in blue represent housing projects located in the unrestricted districts. 
Table 1: Summary Statistics - Housing Projects (-6/+12 months)

\begin{tabular}{|c|c|c|c|c|}
\hline & \multicolumn{2}{|c|}{ Before Restriction } & & After Restriction \\
\hline & Mean & S.D & & Mean \\
\hline \multicolumn{5}{|c|}{ Panel A: All Districts } \\
\hline Avg. Price/m2 & $8,200.41$ & $5,219.12$ & $9,356.20$ & $6,478.49$ \\
\hline Total Transactions & 40.26 & 63.34 & 25.98 & 46.81 \\
\hline Avg. Unit Size(m2) & 110.69 & 47.53 & 106.65 & 47.36 \\
\hline Observations & \multicolumn{2}{|c|}{3,303} & & 7,465 \\
\hline
\end{tabular}

Panel B: Restricted Districts

\begin{tabular}{lcclc}
\hline Avg. Price/m2 & $9,378.54$ & $5,720.57$ & $11,257.92$ & $7,393.86$ \\
Total Transactions & 37.92 & 62.95 & 22.90 & 44.90 \\
Avg. Unit Size(m2) & 106.99 & 45.85 & 103.37 & 45.35 \\
\hline Observations & \multicolumn{2}{c}{2,296} & 4,563 \\
\hline
\end{tabular}

\section{Panel C: Unrestricted Districts}

\begin{tabular}{lcclc}
\hline Avg. Price/m2 & $5,514.23$ & $2,088.27$ & $6,366.01$ & $2,717.28$ \\
Total Transactions & 45.59 & 63.95 & 30.81 & 49.28 \\
Avg. Unit Size(m2) & 119.12 & 50.16 & 111.81 & 49.94 \\
\hline Observations & \multicolumn{3}{c}{1,007} & 2,902 \\
\hline
\end{tabular}

Notes: This table reports the project aggregates in four cities (Chengdu, Guangzhou, Hefei, and Qingdao). The data are broken down between purchase restricted and unrestricted districts, and for 6 months before and 12 months after the imposition of the restrictions. 
Table 2: Summary Statistics: Land Auctions (-6/+12 months)

\begin{tabular}{lcccccc}
\hline & \multicolumn{2}{c}{ Before Restriction } & & \multicolumn{2}{c}{ After Restriction } \\
\cline { 2 - 3 } \cline { 5 - 6 } & Mean & S.D & & Mean & S.D \\
\hline Panel A: All Districts & & & & \\
\hline Avg. Price/m2 of Buildable & $1,636.91$ & $1,964.69$ & & $1,654.94$ & $4,042.24$ \\
Land Area & $46,481.29$ & $46,070.92$ & & $39,918.21$ & $40,160.87$ \\
Buildable Area & $110,199.19$ & $137,017.04$ & & $98,243.17$ & $121,477.48$ \\
Distance to CBD & 31.89 & 22.26 & & 32.07 & 21.58 \\
Auction Type & 0.51 & 0.50 & & 0.49 & 0.50 \\
FSR & 2.43 & 1.39 & & 2.42 & 1.41 \\
\hline Observations & \multicolumn{3}{c}{413} & & \multicolumn{3}{c}{537} \\
\hline
\end{tabular}

Panel B: Restricted Districts

\begin{tabular}{lcccc}
\hline Avg. Price/m2 of Buildable & $2,765.66$ & $2,217.75$ & $2,758.29$ & $6,659.87$ \\
Land Area & $45,703.78$ & $46,786.53$ & $40,001.56$ & $41,512.22$ \\
Buildable Area & $126,513.11$ & $169,296.45$ & $91,087.20$ & $88,064.52$ \\
Distance to CBD & 22.22 & 12.31 & 26.49 & 15.84 \\
Auction Type & 0.45 & 0.50 & 0.50 & 0.50 \\
FSR & 2.93 & 1.53 & 2.63 & 1.42 \\
\hline Observations & \multicolumn{2}{c}{119} & \multicolumn{2}{c}{182} \\
\hline
\end{tabular}

Panel C: Unrestricted Districts

\begin{tabular}{lcccc}
\hline Avg. Price/m2 of Buildable & $1,180.04$ & $1,649.26$ & $1,089.28$ & $1,056.17$ \\
Land Area & $46,796.00$ & $45,854.86$ & $39,875.47$ & $39,509.68$ \\
Buildable Area & $103,595.93$ & $121,259.45$ & $101,911.86$ & $135,419.57$ \\
Distance to CBD & 35.81 & 24.13 & 34.93 & 23.51 \\
Auction Type & 0.53 & 0.50 & 0.49 & 0.50 \\
FSR & 2.23 & 1.27 & 2.32 & 1.40 \\
\hline Observations & \multicolumn{2}{c}{355} \\
\hline
\end{tabular}

Notes: This table reports the district-month level summary statistics for land transactions in districts with and without the purchase restrictions in four cities (Chengdu, Guangzhou, Hefei, and Qingdao), 6 months before and 12 months after the implementation of the restrictions. 
Table 3: District Level DiD - Prices

\begin{tabular}{|c|c|c|c|c|c|c|}
\hline \multirow{2}{*}{$\begin{array}{l}\text { Dependent Variable } \\
\text { Time Window } \\
\text { Model Specification }\end{array}$} & \multicolumn{6}{|c|}{ ln(average transaction price) } \\
\hline & $(1)$ & $(2)$ & $(3)$ & $(1)$ & $(2)$ & $(3)$ \\
\hline Treat*Before & & $\begin{array}{c}0.009 \\
(0.016)\end{array}$ & & & $\begin{array}{c}0.016 \\
(0.017)\end{array}$ & \\
\hline Treat*After & $\begin{array}{c}0.010 \\
(0.024)\end{array}$ & $\begin{array}{c}0.017 \\
(0.026)\end{array}$ & & $\begin{array}{c}0.018 \\
(0.026)\end{array}$ & $\begin{array}{c}0.034 \\
(0.029)\end{array}$ & \\
\hline Treat*Trend & & & $\begin{array}{l}-0.002 \\
(0.004)\end{array}$ & & & $\begin{array}{c}0.003 \\
(0.003)\end{array}$ \\
\hline Treat*Trend*After & & & $\begin{array}{c}0.001 \\
(0.001)\end{array}$ & & & $\begin{array}{l}-0.000 \\
(0.001)\end{array}$ \\
\hline After & $\begin{array}{c}0.002 \\
(0.023)\end{array}$ & & $\begin{array}{l}-0.002 \\
(0.019)\end{array}$ & $\begin{array}{c}0.011 \\
(0.023)\end{array}$ & & $\begin{array}{c}0.047^{* *} \\
(0.020)\end{array}$ \\
\hline Trend & & & $\begin{array}{c}0.015^{* * *} \\
(0.003)\end{array}$ & & & $\begin{array}{c}0.007^{* * *} \\
(0.002)\end{array}$ \\
\hline $\ln ($ size $)$ & $\begin{array}{c}0.039 \\
(0.055)\end{array}$ & $\begin{array}{c}0.039 \\
(0.055)\end{array}$ & $\begin{array}{c}0.039 \\
(0.055)\end{array}$ & $\begin{array}{c}0.081^{*} \\
(0.045)\end{array}$ & $\begin{array}{l}0.081^{*} \\
(0.045)\end{array}$ & $\begin{array}{l}0.083^{*} \\
(0.045)\end{array}$ \\
\hline Constant & $\begin{array}{c}8.653^{* * *} \\
(0.254)\end{array}$ & $\begin{array}{c}8.654^{* * *} \\
(0.254)\end{array}$ & $\begin{array}{c}8.363^{* * *} \\
(0.260)\end{array}$ & $\begin{array}{c}8.461^{* * *} \\
(0.206)\end{array}$ & $\begin{array}{c}8.465^{* * *} \\
(0.205)\end{array}$ & $\begin{array}{c}8.263^{* * *} \\
(0.221)\end{array}$ \\
\hline Observations & 6,779 & 6,779 & 6,779 & 10,768 & 10,768 & 10,768 \\
\hline R-squared & 0.883 & 0.883 & 0.883 & 0.849 & 0.849 & 0.848 \\
\hline Year-Month FE & Yes & Yes & No & Yes & Yes & No \\
\hline Project FE & Yes & Yes & Yes & Yes & Yes & Yes \\
\hline Month FE & No & No & Yes & No & No & Yes \\
\hline
\end{tabular}

Notes: This table shows the difference in individual development project mean log apartment prices per square meter across districts 6 months before and 6-12 months after the introduction of purchase restrictions. Trend starts at 1 for Oct 2008. Standard errors are clustered at the district level and are shown in parentheses under the estimated coefficients. We use ***, **, and ${ }^{*}$ to denote significance at the $1 \%, 5 \%$, and $10 \%$ level, respectively. 
Table 4: District DiD with Longer Windows - Prices

\begin{tabular}{|c|c|c|c|c|c|c|}
\hline \multirow{2}{*}{$\begin{array}{l}\text { Dependent Variable } \\
\text { Time Window } \\
\text { Model Specification }\end{array}$} & \multicolumn{3}{|c|}{$\ln$ (average transaction price) } & \multicolumn{3}{|c|}{$-6 \mathrm{~m}$ to $24 \mathrm{~m}$} \\
\hline & (1) & (2) & (3) & (1) & (2) & (3) \\
\hline Treat*Before & & $\begin{array}{c}0.009 \\
(0.016)\end{array}$ & & & $\begin{array}{c}0.002 \\
(0.017)\end{array}$ & \\
\hline Treat*After & $\begin{array}{c}0.009 \\
(0.027)\end{array}$ & $\begin{array}{c}0.020 \\
(0.028)\end{array}$ & & $\begin{array}{c}0.013 \\
(0.030)\end{array}$ & $\begin{array}{c}0.003 \\
(0.029)\end{array}$ & \\
\hline Treat*Trend & & & $\begin{array}{c}0.000 \\
(0.003)\end{array}$ & & & $\begin{array}{c}0.002 \\
(0.002)\end{array}$ \\
\hline Treat*Trend*After & & & $\begin{array}{c}0.000 \\
(0.001)\end{array}$ & & & $\begin{array}{l}-0.001 \\
(0.001)\end{array}$ \\
\hline After & $\begin{array}{c}0.011 \\
(0.028)\end{array}$ & & $\begin{array}{c}0.126^{* * *} \\
(0.022)\end{array}$ & $\begin{array}{l}-0.032 \\
(0.031)\end{array}$ & & $\begin{array}{c}0.152^{* * *} \\
(0.022)\end{array}$ \\
\hline Trend & & & $\begin{array}{c}0.000 \\
(0.002)\end{array}$ & & & $\begin{array}{c}-0.003^{* *} \\
(0.001)\end{array}$ \\
\hline $\ln ($ size $)$ & $\begin{array}{c}0.039 \\
(0.035)\end{array}$ & $\begin{array}{c}0.039 \\
(0.035)\end{array}$ & $\begin{array}{c}0.034 \\
(0.036)\end{array}$ & $\begin{array}{l}0.074^{*} \\
(0.042)\end{array}$ & $\begin{array}{l}0.074^{*} \\
(0.042)\end{array}$ & $\begin{array}{c}0.066 \\
(0.043)\end{array}$ \\
\hline Constant & $\begin{array}{c}8.639^{* * *} \\
(0.163)\end{array}$ & $\begin{array}{c}8.640^{* * *} \\
(0.162)\end{array}$ & $\begin{array}{c}8.741^{* * *} \\
(0.163)\end{array}$ & $\begin{array}{c}8.442^{* * *} \\
(0.197)\end{array}$ & $\begin{array}{c}8.446^{* * * *} \\
(0.195)\end{array}$ & $\begin{array}{c}8.622^{* * * *} \\
(0.186)\end{array}$ \\
\hline Observations & 14,805 & 14,805 & 14,805 & 20,388 & 20,388 & 20,388 \\
\hline R-squared & 0.837 & 0.837 & 0.835 & 0.833 & 0.833 & 0.830 \\
\hline Year-Month FE & Yes & Yes & No & Yes & Yes & No \\
\hline Project FE & Yes & Yes & Yes & Yes & Yes & Yes \\
\hline Month FE & No & No & Yes & No & No & Yes \\
\hline
\end{tabular}

Notes: This table shows the difference in individual development project mean log apartment prices per square meter across districts 6 months before and 18-24 months after the introduction of purchase restrictions. Trend starts at 1 for Oct 2008. Standard errors are clustered at the district level and are shown in parentheses under the estimated coefficients. We use ${ }^{* * *},{ }^{* *}$, and ${ }^{*}$ to denote significance at the $1 \%, 5 \%$, and $10 \%$ level, respectively. 
Table 5: District Level DiD - Transactions

\begin{tabular}{|c|c|c|c|c|c|c|}
\hline \multirow{3}{*}{$\begin{array}{l}\text { Dependent Variable } \\
\text { Time Window } \\
\text { Model Specification }\end{array}$} & \multicolumn{6}{|c|}{$\ln$ (number of transactions) } \\
\hline & \multicolumn{3}{|c|}{$-6 \mathrm{~m}$ to $6 \mathrm{~m}$} & \multicolumn{3}{|c|}{$-6 \mathrm{~m}$ to $12 \mathrm{~m}$} \\
\hline & $(1)$ & $(2)$ & $(3)$ & $(1)$ & $(2)$ & $(3)$ \\
\hline Treat*Before & & $\begin{array}{l}-0.108 \\
(0.083)\end{array}$ & & & $\begin{array}{l}-0.070 \\
(0.087)\end{array}$ & \\
\hline Treat*After & $\begin{array}{c}-0.423^{* * *} \\
(0.102)\end{array}$ & $\begin{array}{c}-0.618^{* * *} \\
(0.090)\end{array}$ & & $\begin{array}{c}-0.299 * * * \\
(0.095)\end{array}$ & $\begin{array}{c}-0.431^{* * *} \\
(0.093)\end{array}$ & \\
\hline Treat*Trend & & & $\begin{array}{l}-0.005 \\
(0.024)\end{array}$ & & & $\begin{array}{c}0.049^{* * *} \\
(0.017)\end{array}$ \\
\hline Treat*Trend*After & & & $\begin{array}{l}-0.012^{*} \\
(0.007)\end{array}$ & & & $\begin{array}{c}-0.022^{* * *} \\
(0.006)\end{array}$ \\
\hline After & $\begin{array}{c}-0.286^{*} \\
(0.146)\end{array}$ & & $\begin{array}{c}-0.534^{* * *} \\
(0.168)\end{array}$ & $\begin{array}{c}-0.217^{*} \\
(0.120)\end{array}$ & & $\begin{array}{l}-0.070 \\
(0.143)\end{array}$ \\
\hline Trend & & & $\begin{array}{c}0.016 \\
(0.017)\end{array}$ & & & $\begin{array}{c}-0.068^{* * *} \\
(0.011)\end{array}$ \\
\hline Constant & $\begin{array}{c}3.144^{* * *} \\
(0.139)\end{array}$ & $\begin{array}{c}3.170 * * * \\
(0.148)\end{array}$ & $\begin{array}{c}2.561^{* * *} \\
(0.373)\end{array}$ & $\begin{array}{c}3.361^{* * *} \\
(0.145)\end{array}$ & $\begin{array}{c}3.366^{* * * *} \\
(0.154)\end{array}$ & $\begin{array}{c}3.800^{* * *} \\
(0.258)\end{array}$ \\
\hline Observations & 6,779 & 6,779 & 6,779 & 10,768 & 10,768 & 10,768 \\
\hline R-squared & 0.666 & 0.666 & 0.655 & 0.619 & 0.618 & 0.606 \\
\hline Year-Month FE & Yes & Yes & No & Yes & Yes & No \\
\hline Project FE & Yes & Yes & Yes & Yes & Yes & Yes \\
\hline Month FE & No & No & Yes & No & No & Yes \\
\hline
\end{tabular}

Notes: This table shows the difference in individual development project mean log transaction volume across districts 6 months before and 6-12 months after the introduction of purchase restrictions. Trend starts at 1 for Oct 2008. Standard errors are clustered at the district level and are shown in parentheses under the estimated coefficients. We use ${ }^{* * *}$, ${ }^{* *}$, and ${ }^{*}$ to denote significance at the $1 \%, 5 \%$, and $10 \%$ level, respectively. 
Table 6: District DiD with Longer Windows - Transactions

\begin{tabular}{|c|c|c|c|c|c|c|}
\hline \multirow{3}{*}{$\begin{array}{l}\text { Dependent Variable } \\
\text { Time Window } \\
\text { Model Specification }\end{array}$} & \multicolumn{6}{|c|}{$\ln$ (number of transactions) } \\
\hline & \multicolumn{3}{|c|}{$-6 \mathrm{~m}$ to $18 \mathrm{~m}$} & \multicolumn{3}{|c|}{$-6 m$ to $24 m$} \\
\hline & (1) & $(2)$ & $(3)$ & (1) & $(2)$ & $(3)$ \\
\hline & & $\begin{array}{l}-0.065 \\
(0.090)\end{array}$ & & & $\begin{array}{l}-0.079 \\
(0.092)\end{array}$ & \\
\hline Treat*After & $\begin{array}{c}-0.283^{* * *} \\
(0.098)\end{array}$ & $\begin{array}{c}-0.382^{* * *} \\
(0.102)\end{array}$ & & $\begin{array}{c}-0.243^{* *} \\
(0.094)\end{array}$ & $\begin{array}{c}-0.385^{* * *} \\
(0.108)\end{array}$ & \\
\hline Treat*Trend & & & $\begin{array}{c}0.025^{*} \\
(0.015)\end{array}$ & & & $\begin{array}{l}0.018^{*} \\
(0.010)\end{array}$ \\
\hline Treat*Trend*After & & & $\begin{array}{c}-0.016^{* * *} \\
(0.006)\end{array}$ & & & $\begin{array}{c}-0.012^{* *} \\
(0.005)\end{array}$ \\
\hline After & $\begin{array}{l}-0.144 \\
(0.117)\end{array}$ & & $\begin{array}{c}-0.300^{* *} \\
(0.144)\end{array}$ & $\begin{array}{c}-0.236^{*} \\
(0.120)\end{array}$ & & $\begin{array}{c}-0.688^{* * *} \\
(0.108)\end{array}$ \\
\hline Trend & & & $\begin{array}{c}-0.023^{* *} \\
(0.009)\end{array}$ & & & $\begin{array}{l}-0.007 \\
(0.006)\end{array}$ \\
\hline Constant & $\begin{array}{c}3.409 * * * \\
(0.153)\end{array}$ & $\begin{array}{c}3.401^{* * *} \\
(0.161)\end{array}$ & $\begin{array}{c}3.280^{* * * *} \\
(0.206)\end{array}$ & $\begin{array}{c}3.372^{* * *} \\
(0.160)\end{array}$ & $\begin{array}{c}3.359 * * * \\
(0.169)\end{array}$ & $\begin{array}{c}2.951^{* * *} \\
(0.127)\end{array}$ \\
\hline Observations & 14,805 & 14,805 & 14,805 & 20,388 & 20,388 & 20,388 \\
\hline R-squared & 0.588 & 0.588 & 0.568 & 0.551 & 0.550 & 0.535 \\
\hline Year-Month FE & Yes & Yes & No & Yes & Yes & No \\
\hline Project FE & Yes & Yes & Yes & Yes & Yes & Yes \\
\hline Month FE & No & No & Yes & No & No & Yes \\
\hline
\end{tabular}

Notes: This table shows the difference in individual development project mean log transaction volume across districts 6 months before and 18-24 months after the introduction of purchase restrictions. Trend starts at 1 for Oct 2008. Standard errors are clustered at the district level and are shown in parentheses under the estimated coefficients. We use ${ }^{* * *}$, ${ }^{* *}$, and $*$ to denote significance at the $1 \%, 5 \%$, and $10 \%$ level, respectively. 
Table 7: 3km Border Band DiD - Prices

\begin{tabular}{|c|c|c|c|c|c|c|c|}
\hline \multirow{3}{*}{$\begin{array}{l}\text { Dependent Variable } \\
\text { Time Window } \\
\text { Model Specification }\end{array}$} & \multicolumn{7}{|c|}{ ln(average transaction price) } \\
\hline & \multicolumn{3}{|c|}{$-6 \mathrm{~m}$ to $6 \mathrm{~m}$} & & \multicolumn{3}{|c|}{$-6 \mathrm{~m}$ to $12 \mathrm{~m}$} \\
\hline & $(1)$ & $(2)$ & $(3)$ & & $(1)$ & $(2)$ & $(3)$ \\
\hline Treat*Before & & $\begin{array}{l}-0.001 \\
(0.020)\end{array}$ & & & $\begin{array}{c}0.014 \\
(0.023)\end{array}$ & & \\
\hline Treat*After & $\begin{array}{c}0.003 \\
(0.022)\end{array}$ & $\begin{array}{c}0.012 \\
(0.028)\end{array}$ & & $\begin{array}{c}0.017 \\
(0.023)\end{array}$ & $\begin{array}{c}0.035 \\
(0.029)\end{array}$ & & \\
\hline Treat*Trend & & & $\begin{array}{l}-0.004 \\
(0.004)\end{array}$ & & & $\begin{array}{c}0.004 \\
(0.004)\end{array}$ & \\
\hline Treat*Trend*After & & & $\begin{array}{c}0.001 \\
(0.001)\end{array}$ & & & $\begin{array}{l}-0.001 \\
(0.001)\end{array}$ & \\
\hline After & $\begin{array}{c}0.036 \\
(0.027)\end{array}$ & & $\begin{array}{c}0.020 \\
(0.030)\end{array}$ & $\begin{array}{c}0.040 \\
(0.025)\end{array}$ & & $\begin{array}{c}0.077^{* * *} \\
(0.028)\end{array}$ & \\
\hline Trend & & & $\begin{array}{c}0.013^{* * *} \\
(0.003)\end{array}$ & & & $\begin{array}{l}0.005^{*} \\
(0.003)\end{array}$ & \\
\hline $\ln ($ size $)$ & $\begin{array}{c}0.017 \\
(0.063)\end{array}$ & $\begin{array}{c}0.016 \\
(0.062)\end{array}$ & $\begin{array}{c}0.018 \\
(0.063)\end{array}$ & $\begin{array}{c}0.067 \\
(0.053)\end{array}$ & $\begin{array}{c}0.066 \\
(0.053)\end{array}$ & $\begin{array}{c}0.067 \\
(0.052)\end{array}$ & \\
\hline Constant & $\begin{array}{c}8.755^{* * *} \\
(0.292)\end{array}$ & $\begin{array}{c}8.748^{* * *} \\
(0.293)\end{array}$ & $\begin{array}{c}8.517^{* * *} \\
(0.290)\end{array}$ & $\begin{array}{c}8.585^{* * *} \\
(0.247)\end{array}$ & $\begin{array}{c}8.586 \text { *** } \\
(0.248)\end{array}$ & $\begin{array}{c}8.372^{* * *} \\
(0.261)\end{array}$ & \\
\hline Observations & 4,431 & 4,431 & 4,431 & 7,130 & 7,130 & 7,130 & \\
\hline R-squared & 0.855 & 0.855 & 0.855 & 0.811 & 0.811 & 0.811 & \\
\hline Year-Month FE & Yes & Yes & No & Yes & Yes & No & \\
\hline Project FE & Yes & Yes & Yes & Yes & Yes & Yes & \\
\hline Month FE & No & No & Yes & No & No & Yes & \\
\hline
\end{tabular}

Notes: This table presents the same regression as those shown in Table 3 using a sample that contains projects within $3 \mathrm{~km}$ of the border between districts where purchase restrictions are imposed and those where they are not. The dependent variable is log average transaction price. Trend starts at 1 for Oct 2008. Standard errors are clustered at the district level and are shown in parentheses under the estimated coefficients. We use ${ }^{* * *},{ }^{* *}$, and ${ }^{*}$ to denote significance at the $1 \%, 5 \%$, and $10 \%$ level, respectively. 
Table 8: 3km Border Band DID - Transactions

\begin{tabular}{|c|c|c|c|c|c|c|}
\hline \multirow{3}{*}{$\begin{array}{l}\text { Dependent Variable } \\
\text { Time Window } \\
\text { Model Specification }\end{array}$} & \multicolumn{6}{|c|}{ ln(number of transactions) } \\
\hline & \multicolumn{3}{|c|}{$-6 \mathrm{~m}$ to $6 \mathrm{~m}$} & \multicolumn{3}{|c|}{$-6 \mathrm{~m}$ to $12 \mathrm{~m}$} \\
\hline & (1) & $(2)$ & $(3)$ & (1) & $(2)$ & $(3)$ \\
\hline Treat*Before & & $\begin{array}{l}-0.109 \\
(0.094)\end{array}$ & & & $\begin{array}{l}-0.054 \\
(0.099)\end{array}$ & \\
\hline Treat*After & $\begin{array}{c}-0.478^{* * *} \\
(0.134)\end{array}$ & $\begin{array}{c}-0.619^{* * *} \\
(0.133)\end{array}$ & & $\begin{array}{c}-0.308^{* *} \\
(0.127)\end{array}$ & $\begin{array}{c}-0.422^{* * *} \\
(0.136)\end{array}$ & \\
\hline Treat*Trend & & & $\begin{array}{l}-0.012 \\
(0.037)\end{array}$ & & & $\begin{array}{c}0.077^{* * *} \\
(0.022)\end{array}$ \\
\hline Treat*Trend*After & & & $\begin{array}{c}-0.012^{* *} \\
(0.005)\end{array}$ & & & $\begin{array}{c}-0.031^{* * *} \\
(0.007)\end{array}$ \\
\hline After & $\begin{array}{c}-0.247 \\
(0.160)\end{array}$ & & $\begin{array}{l}-0.382 \\
(0.235)\end{array}$ & $\begin{array}{c}-0.309^{*} \\
(0.165)\end{array}$ & & $\begin{array}{l}-0.149 \\
(0.195)\end{array}$ \\
\hline Trend & & & $\begin{array}{c}0.001 \\
(0.025)\end{array}$ & & & $\begin{array}{c}-0.064^{* * *} \\
(0.017)\end{array}$ \\
\hline Constant & $\begin{array}{c}3.219 * * * \\
(0.234)\end{array}$ & $\begin{array}{c}3.265^{* * *} \\
(0.256)\end{array}$ & $\begin{array}{c}3.322^{* * *} \\
(0.403)\end{array}$ & $\begin{array}{c}3.383^{* * *} \\
(0.257)\end{array}$ & $\begin{array}{c}3.428^{* * *} \\
(0.266)\end{array}$ & $\begin{array}{c}3.284^{* * *} \\
(0.361)\end{array}$ \\
\hline Observations & 4,431 & 4,431 & 4,431 & 7,130 & 7,130 & 7,130 \\
\hline R-squared & 0.668 & 0.668 & 0.666 & 0.618 & 0.617 & 0.608 \\
\hline Year-Month FE & Yes & Yes & No & Yes & Yes & No \\
\hline Project FE & Yes & Yes & Yes & Yes & Yes & Yes \\
\hline Month FE & No & No & Yes & No & No & Yes \\
\hline
\end{tabular}

Notes: This table presents the same regression as those shown in Table 5. using a sample that contains projects within $3 \mathrm{~km}$ of the border between districts where purchase restrictions are imposed and those where they are not. The dependent variable is log transaction volume. Trend starts at 1 for Oct 2008. Standard errors are clustered at the district level and are shown in parentheses under the estimated coefficients. We use ${ }^{* *},{ }^{* *}$, and ${ }^{*}$ to denote significance at the $1 \%, 5 \%$, and $10 \%$ level, respectively. 
Table 9: Falsification Tests: Placebo 3 km Border

\begin{tabular}{lccccc}
\hline Dependent Variable & \multicolumn{2}{c}{$\ln ($ price $)$} & & \multicolumn{2}{c}{$\ln ($ volume $)$} \\
\cline { 2 - 3 } \cline { 5 - 6 } Time Window & $-6 \mathrm{~m}$ to $6 \mathrm{~m}$ & $-6 \mathrm{~m}$ to $12 \mathrm{~m}$ & & $-6 \mathrm{~m}$ to $6 \mathrm{~m}$ & $-6 \mathrm{~m}$ to $12 \mathrm{~m}$ \\
\hline Treat*After & -0.029 & -0.028 & & 0.058 & -0.001 \\
& $(0.025)$ & $(0.032)$ & & $(0.148)$ & $(0.150)$ \\
After & $0.057^{* *}$ & $0.065^{* *}$ & & $-0.683^{* * *}$ & $-0.658^{* * *}$ \\
& $(0.022)$ & $(0.024)$ & & $(0.110)$ & $(0.141)$ \\
$\ln ($ size) & 0.004 & 0.027 & & & \\
& $(0.075)$ & $(0.053)$ & & \\
Constant & $8.963^{* * *}$ & $8.896^{* * *}$ & & $3.160^{* * *}$ & $3.219^{* * *}$ \\
& $(0.345)$ & $(0.252)$ & & $(0.197)$ & $(0.155)$ \\
& & & & & \\
Observations & 3,388 & 5,239 & & 3,388 & 5,239 \\
R-squared & 0.854 & 0.807 & & 0.652 & 0.606 \\
Year-Month FE & Yes & Yes & & Yes & Yes \\
Project FE & Yes & Yes & & Yes & Yes \\
\hline
\end{tabular}

Notes: This table reports the results of geographic falsification test using specification (1). The sample includes a $3 \mathrm{~km}$ band in districts that do not have restrictions. The treatment group includes housing projects lie $0-3 \mathrm{~km}$ from the border in the non-restricted district. The control group contains housing projects lie $3-6 \mathrm{~km}$ from the border in the non-restricted district. Standard errors are clustered at the district level and are shown in parentheses under the estimated coefficients. We use $^{* * *},{ }^{* *}$, and $*$ to denote significance at the $1 \%, 5 \%$, and $10 \%$ level, respectively. 
Table 10: Falsification Tests: Placebo Restriction Date (Quantity Only)

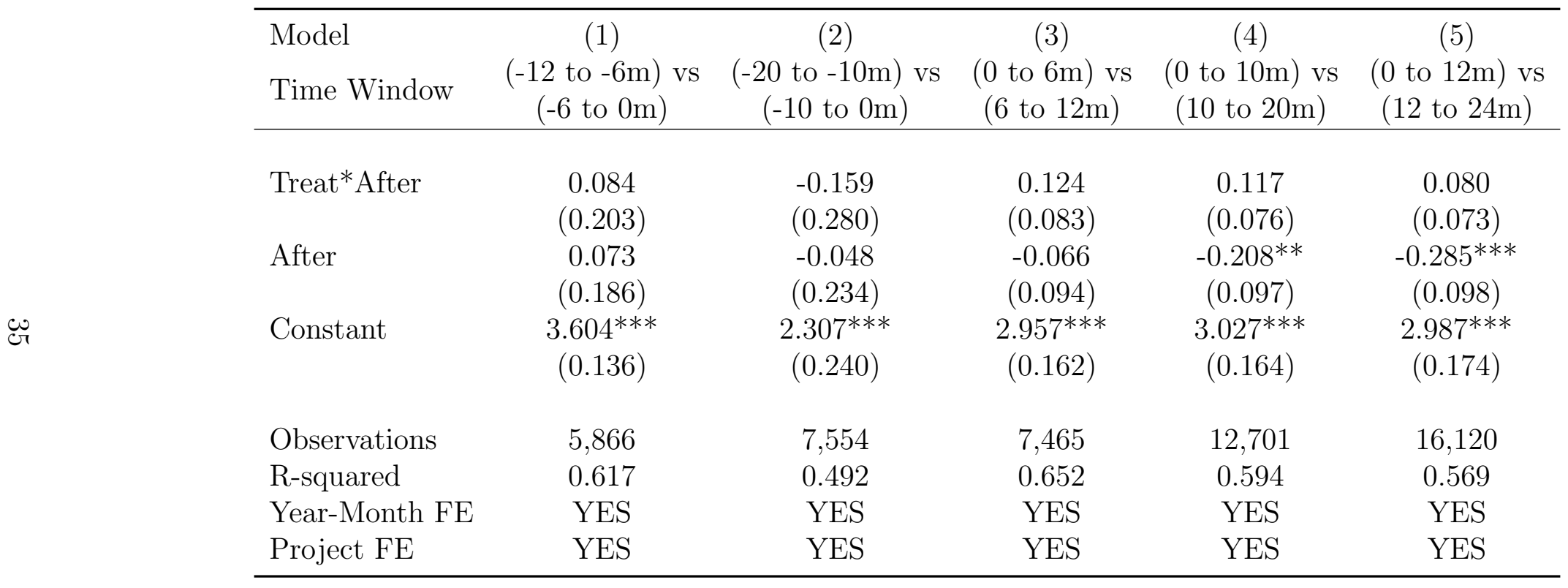

Notes: This table reports the results of time falsification test using specification (1). The dependent variable is log transaction volume. Model 1 to 5 have a placebo restriction assigned to a random month, and the regressions differ by window length. Standard errors are clustered at the district level and are shown in parentheses under the estimated coefficients. We use ${ }^{* * *},{ }^{* *}$, and ${ }^{*}$ to denote significance at the $1 \%, 5 \%$, and $10 \%$ level, respectively. 
Table 11: Land Supply Analysis: Price (Transaction Level)

\begin{tabular}{|c|c|c|c|c|c|c|}
\hline \multirow{2}{*}{$\begin{array}{l}\text { Dependent Variable } \\
\text { Time Window } \\
\text { Model Specification }\end{array}$} & \multicolumn{6}{|c|}{ In(transaction price/buildable land area) } \\
\hline & (1) & (2) & (3) & (1) & $(2)$ & (3) \\
\hline Treat*Before & & $\begin{array}{c}0.032 \\
(0.212)\end{array}$ & & & $\begin{array}{l}-0.053 \\
(0.206)\end{array}$ & \\
\hline Treat*After & $\begin{array}{l}-0.051 \\
(0.168)\end{array}$ & $\begin{array}{l}-0.020 \\
(0.244)\end{array}$ & & $\begin{array}{l}-0.067 \\
(0.175)\end{array}$ & $\begin{array}{l}-0.107 \\
(0.221)\end{array}$ & \\
\hline Treat*Trend & & & $\begin{array}{c}-0.074^{*} \\
(0.039)\end{array}$ & & & $\begin{array}{l}-0.011 \\
(0.021)\end{array}$ \\
\hline Treat*Trend*After & & & $\begin{array}{c}0.009 \\
(0.008)\end{array}$ & & & $\begin{array}{l}-0.000 \\
(0.007)\end{array}$ \\
\hline After & $\begin{array}{c}0.059 \\
(0.202)\end{array}$ & & $\begin{array}{l}-0.086 \\
(0.212)\end{array}$ & $\begin{array}{l}-0.034 \\
(0.176)\end{array}$ & & $\begin{array}{c}0.049 \\
(0.157)\end{array}$ \\
\hline Trend & & & $\begin{array}{c}0.033 \\
(0.035)\end{array}$ & & & $\begin{array}{l}-0.003 \\
(0.015)\end{array}$ \\
\hline Auction Type & $\begin{array}{l}-0.104 \\
(0.172)\end{array}$ & $\begin{array}{l}-0.103 \\
(0.172)\end{array}$ & $\begin{array}{l}-0.093 \\
(0.168)\end{array}$ & $\begin{array}{l}-0.149 \\
(0.132)\end{array}$ & $\begin{array}{l}-0.150 \\
(0.132)\end{array}$ & $\begin{array}{l}-0.126 \\
(0.126)\end{array}$ \\
\hline $\ln ($ size $)$ & $\begin{array}{c}-0.127^{* * *} \\
(0.044)\end{array}$ & $\begin{array}{c}-0.127^{* * *} \\
(0.045)\end{array}$ & $\begin{array}{c}-0.122 * * * \\
(0.045)\end{array}$ & $\begin{array}{c}-0.103^{* * *} \\
(0.036)\end{array}$ & $\begin{array}{c}-0.103^{* * *} \\
(0.036)\end{array}$ & $\begin{array}{c}-0.099^{* * *} \\
(0.036)\end{array}$ \\
\hline FSR & $\begin{array}{c}-0.219^{* * * *} \\
(0.040)\end{array}$ & $\begin{array}{c}-0.218^{* * *} \\
(0.041)\end{array}$ & $\begin{array}{c}-0.225^{* * * *} \\
(0.038)\end{array}$ & $\begin{array}{c}-0.186^{* * *} \\
(0.035)\end{array}$ & $\begin{array}{c}-0.187^{* * *} \\
(0.035)\end{array}$ & $\begin{array}{c}-0.190^{* * * *} \\
(0.038)\end{array}$ \\
\hline $\ln ($ distance to CBD) & $\begin{array}{c}-0.212^{* *} \\
(0.100)\end{array}$ & $\begin{array}{c}-0.213^{* *} \\
(0.102)\end{array}$ & $\begin{array}{c}-0.204^{* *} \\
(0.097)\end{array}$ & $\begin{array}{c}-0.229^{* *} \\
(0.095)\end{array}$ & $\begin{array}{c}-0.228^{* *} \\
(0.096)\end{array}$ & $\begin{array}{c}-0.244^{* *} \\
(0.101)\end{array}$ \\
\hline Constant & $\begin{array}{c}9.822^{* * *} \\
(0.615)\end{array}$ & $\begin{array}{c}9.804^{* * *} \\
(0.656)\end{array}$ & $\begin{array}{c}9.132^{* * *} \\
(0.884)\end{array}$ & $\begin{array}{c}9.578^{* * *} \\
(0.727)\end{array}$ & $\begin{array}{c}9.578^{* * *} \\
(0.731)\end{array}$ & $\begin{array}{c}9.548^{* * *} \\
(0.602)\end{array}$ \\
\hline Obser & 673 & 673 & 673 & 950 & 950 & 950 \\
\hline R-squared & 0.660 & 0.660 & 0.662 & 0.599 & 0.599 & 0.589 \\
\hline Year-Month FE & Yes & Yes & No & Yes & Yes & No \\
\hline Land Type FE & Yes & Yes & Yes & Yes & Yes & Yes \\
\hline District FE & Yes & Yes & Yes & Yes & Yes & Yes \\
\hline Month FE & No & No & Yes & No & No & Yes \\
\hline
\end{tabular}

Notes: This table presents the price effects in the land auctions in response to the purchase restriction 6 months before and 6-12 months after the introduction of purchase restrictions. The dependent variable is the log of price per buildable area. The Trend is a time trend variable equals 1 for Oct 2008. Standard errors are clustered at the district level and are shown in parentheses under the estimated coefficients. We use ${ }^{* * *},{ }^{* *}$, and $*$ to denote significance at the $1 \%, 5 \%$, and $10 \%$ level, respectively. 
Table 12: Land Supply Analysis: Quantity (District Month Level)

\begin{tabular}{|c|c|c|c|c|c|c|}
\hline \multirow{2}{*}{$\begin{array}{l}\text { Dependent Variable } \\
\text { Time Window } \\
\text { Model Specification }\end{array}$} & \multicolumn{3}{|c|}{$\begin{array}{c}\ln \text { (number of transactions) } \\
-6 \mathrm{~m} \text { to } 6 \mathrm{~m}\end{array}$} & \multicolumn{3}{|c|}{$-6 \mathrm{~m}$ to $12 \mathrm{~m}$} \\
\hline & (1) & $(2)$ & $(3)$ & (1) & (2) & (3) \\
\hline Treat*Before & & $\begin{array}{l}-0.065 \\
(0.150)\end{array}$ & & & $\begin{array}{c}0.015 \\
(0.143)\end{array}$ & \\
\hline Treat*After & $\begin{array}{c}0.038 \\
(0.201)\end{array}$ & $\begin{array}{l}-0.033 \\
(0.215)\end{array}$ & & $\begin{array}{c}0.025 \\
(0.163)\end{array}$ & $\begin{array}{l}-0.002 \\
(0.153)\end{array}$ & \\
\hline Treat*Trend & & & $\begin{array}{l}-0.089 \\
(0.070)\end{array}$ & & & $\begin{array}{c}0.004 \\
(0.034)\end{array}$ \\
\hline Treat*Trend*After & & & $\begin{array}{c}0.019 \\
(0.017)\end{array}$ & & & $\begin{array}{c}0.000 \\
(0.010)\end{array}$ \\
\hline After & $\begin{array}{l}-0.076 \\
(0.286)\end{array}$ & & $\begin{array}{l}-0.346 \\
(0.417)\end{array}$ & $\begin{array}{l}-0.155 \\
(0.248)\end{array}$ & & $\begin{array}{l}-0.063 \\
(0.236)\end{array}$ \\
\hline Trend & & & $\begin{array}{c}0.066 \\
(0.059)\end{array}$ & & & $\begin{array}{l}-0.006 \\
(0.018)\end{array}$ \\
\hline Constant & $\begin{array}{c}0.474^{* *} \\
(0.212)\end{array}$ & $\begin{array}{c}0.483^{* *} \\
(0.189)\end{array}$ & $\begin{array}{c}0.423 \\
(1.060)\end{array}$ & $\begin{array}{c}0.437^{* * *} \\
(0.149)\end{array}$ & $\begin{array}{c}0.469^{* * *} \\
(0.147)\end{array}$ & $\begin{array}{l}0.949^{*} \\
(0.478)\end{array}$ \\
\hline Observations & 222 & 222 & 222 & 341 & 341 & 341 \\
\hline R-squared & 0.570 & 0.570 & 0.559 & 0.515 & 0.514 & 0.474 \\
\hline Year-Month FE & Yes & Yes & No & Yes & Yes & No \\
\hline District FE & Yes & Yes & Yes & Yes & Yes & Yes \\
\hline Month FE & No & No & Yes & No & No & Yes \\
\hline
\end{tabular}

Notes: This table presents the price effects in the land auctions in response to the purchase restriction 6 months before and 6-12 months after the introduction of purchase restrictions. The dependent variable is the log transaction volume. The Trend is a time trend variable equals 1 for Oct 2008. Standard errors are clustered at the district level and are shown in parentheses under the estimated coefficients. We use ${ }^{* * *},{ }^{* *}$, and $*$ to denote significance at the $1 \%, 5 \%$, and $10 \%$ level, respectively. 
Table 13: Land Supply Analysis: Buildable Area (Transaction Level)

\begin{tabular}{|c|c|c|c|c|c|c|}
\hline \multirow{3}{*}{$\begin{array}{l}\text { Dependent Variable } \\
\text { Time Window } \\
\text { Model Specification }\end{array}$} & \multicolumn{6}{|c|}{ ln(buildable land area) } \\
\hline & \multicolumn{3}{|c|}{$-6 \mathrm{~m}$ to $6 \mathrm{~m}$} & \multicolumn{3}{|c|}{$-6 \mathrm{~m}$ to $12 \mathrm{~m}$} \\
\hline & (1) & (2) & (3) & (1) & $(2)$ & (3) \\
\hline Treat*Before & & $\begin{array}{l}-0.101 \\
(0.412)\end{array}$ & & & $\begin{array}{l}-0.097 \\
(0.363)\end{array}$ & \\
\hline Treat*After & $\begin{array}{c}-0.409 \\
(0.328)\end{array}$ & $\begin{array}{c}-0.469 \\
(0.467)\end{array}$ & & $\begin{array}{l}-0.352 \\
(0.276)\end{array}$ & $\begin{array}{c}-0.434 \\
(0.366)\end{array}$ & \\
\hline Treat*Trend & & & $\begin{array}{c}0.087 \\
(0.094)\end{array}$ & & & $\begin{array}{c}-0.100^{*} \\
(0.058)\end{array}$ \\
\hline Treat*Trend*After & & & $\begin{array}{l}-0.014 \\
(0.021)\end{array}$ & & & $\begin{array}{c}0.026 \\
(0.019)\end{array}$ \\
\hline After & $\begin{array}{c}0.044 \\
(0.382)\end{array}$ & & $\begin{array}{c}0.086 \\
(0.455)\end{array}$ & $\begin{array}{l}-0.120 \\
(0.305)\end{array}$ & & $\begin{array}{l}-0.383 \\
(0.347)\end{array}$ \\
\hline Trend & & & $\begin{array}{l}-0.022 \\
(0.077)\end{array}$ & & & $\begin{array}{c}0.027 \\
(0.034)\end{array}$ \\
\hline Auction Type & $\begin{array}{c}0.189 \\
(0.188)\end{array}$ & $\begin{array}{c}0.187 \\
(0.187)\end{array}$ & $\begin{array}{c}0.158 \\
(0.195)\end{array}$ & $\begin{array}{c}0.168 \\
(0.157)\end{array}$ & $\begin{array}{c}0.167 \\
(0.155)\end{array}$ & $\begin{array}{c}0.197 \\
(0.162)\end{array}$ \\
\hline $\ln ($ distance to CBD) & $\begin{array}{l}-0.066 \\
(0.105)\end{array}$ & $\begin{array}{l}-0.065 \\
(0.103)\end{array}$ & $\begin{array}{l}-0.071 \\
(0.101)\end{array}$ & $\begin{array}{l}-0.150 \\
(0.100)\end{array}$ & $\begin{array}{l}-0.149 \\
(0.100)\end{array}$ & $\begin{array}{l}-0.164 \\
(0.105)\end{array}$ \\
\hline Constant & $\begin{array}{c}11.764^{* * *} \\
(1.034)\end{array}$ & $\begin{array}{c}11.723^{* * *} \\
(1.022)\end{array}$ & $\begin{array}{c}11.395^{* * *} \\
(1.679)\end{array}$ & $\begin{array}{c}11.906^{* * *} \\
(0.665)\end{array}$ & $\begin{array}{c}11.922^{* * *} \\
(0.726)\end{array}$ & $\begin{array}{c}11.918^{* * *} \\
(0.589)\end{array}$ \\
\hline Observations & 673 & 673 & 673 & 950 & 950 & 950 \\
\hline R-squared & 0.534 & 0.534 & 0.527 & 0.457 & 0.457 & 0.443 \\
\hline Year-Month FE & Yes & Yes & No & Yes & Yes & No \\
\hline Land Type FE & Yes & Yes & Yes & Yes & Yes & Yes \\
\hline District FE & Yes & Yes & Yes & Yes & Yes & Yes \\
\hline Month FE & No & No & Yes & No & No & Yes \\
\hline
\end{tabular}

Notes: This table presents the price effects in the land auctions in response to the purchase restriction 6 months before and 6-12 months after the introduction of purchase restrictions. The dependent variable is the log buildable area. The Trend is a time trend variable equals 1 for Oct 2008. Standard errors are clustered at the district level and are shown in parentheses under the estimated coefficients. We use ${ }^{* * *},{ }^{* *}$, and ${ }^{*}$ to denote significance at the $1 \%, 5 \%$, and $10 \%$ level, respectively. 


\section{APPENDICES}

Table A-1: Policy Summary by City

\begin{tabular}{|c|c|c|c|c|}
\hline City & Policy Date & Treated Districts & Control Districts & Policy Details \\
\hline Hefei & Mar 31, 2011 & $\begin{array}{l}\text { Baohe District, } \\
\text { Luyang District, } \\
\text { Yaohai District, } \\
\text { Shushan District }\end{array}$ & $\begin{array}{l}\text { Beicheng District, } \\
\text { Zhengwu District, } \\
\text { Xinzhan District, } \\
\text { Binhu New District, } \\
\text { Jinkai District, } \\
\text { Gaoxin District }\end{array}$ & $\begin{array}{l}\text { Residents are not allowed to purchase the } 3^{\text {rd }} \text { home; } \\
\text { Non-residents are not allowed to purchase the } 2^{\text {nd }} \text { home; } \\
\text { Restrictions only apply to properties in selected districts. }\end{array}$ \\
\hline Guangzhou & Oct 15,2010 & $\begin{array}{l}\text { Tianhe District, } \\
\text { Fanyu District, } \\
\text { Baiyun District, } \\
\text { Haizhu District, } \\
\text { Huadu District, } \\
\text { Liwan District, } \\
\text { Luogang District, } \\
\text { Yuexiu District, } \\
\text { Huangpu District }\end{array}$ & $\begin{array}{l}\text { Conghua District, } \\
\text { Nansha District }\end{array}$ & $\begin{array}{l}\text { Residents are allowed to purchase an additional home; } \\
\text { Non-residents are not allowed to purchase any homes; } \\
\text { Restrictions only apply to properties in the urban area, } \\
\text { suburban areas are not affected. }\end{array}$ \\
\hline Chengdu & Feb 15, 2011 & $\begin{array}{l}\text { Chenghua District, } \\
\text { Wuhou District, } \\
\text { Jinniu District, } \\
\text { Jinjiang District, } \\
\text { Qingyang District, } \\
\text { Gaoxin District, }\end{array}$ & $\begin{array}{l}\text { Xindu District, } \\
\text { Wenjiang District, } \\
\text { Pi County, } \\
\text { Dujiangyan County, } \\
\text { Qingbaijiang District, } \\
\text { Longquanyi District }\end{array}$ & $\begin{array}{l}\text { Residents are not allowed to purchase the } 3^{\text {rd }} \text { home; } \\
\text { Non-residents are not allowed to purchase the } 2^{\text {nd }} \text { home; } \\
\text { Restrictions only apply to properties in selected districts. }\end{array}$ \\
\hline Qingdao & Jan 31,2011 & $\begin{array}{l}\text { Sifang District, } \\
\text { Shinan District, } \\
\text { Chengyang District, } \\
\text { Laoshan District, } \\
\text { Shibei District, } \\
\text { Licang District, } \\
\text { Huangdao District }\end{array}$ & $\begin{array}{l}\text { Jimo, } \\
\text { Pingdu, } \\
\text { Jiaonan, } \\
\text { Jiaozhou, } \\
\text { Laixi }\end{array}$ & $\begin{array}{l}\text { Residents are not allowed to purchase the } 3^{\text {rd }} \text { home; } \\
\text { Non-residents are not allowed to purchase the } 2^{\text {nd }} \text { home; } \\
\text { Purchase restriction only applies to the selected districts. }\end{array}$ \\
\hline
\end{tabular}


Table A-2: Descriptive Statistics of Housing Projects by City (-6/ +12 months)

\begin{tabular}{|c|c|c|c|c|c|c|c|c|}
\hline & \multicolumn{4}{|c|}{ Control } & \multicolumn{4}{|c|}{ Treat } \\
\hline & \multicolumn{2}{|c|}{ Before } & \multicolumn{2}{|c|}{ After } & \multicolumn{2}{|c|}{ Before } & \multicolumn{2}{|c|}{ After } \\
\hline & Mean & S.D & Mean & S.D & Mean & S.D & Mean & S.D \\
\hline \multicolumn{9}{|l|}{ City: Hefei } \\
\hline Avg. Price/m2 & $5,237.92$ & $1,393.55$ & $6,651.88$ & $3,345.39$ & $5,792.35$ & $1,515.73$ & $7,628.54$ & $4,547.24$ \\
\hline Total Transactions & 23.32 & 28.55 & 13.39 & 24.03 & 25.42 & 48.90 & 15.25 & 25.90 \\
\hline Avg. Unit Size $\left(m^{2}\right)$ & 105.94 & 35.48 & 90.52 & 42.49 & 98.72 & 36.60 & 85.05 & 39.33 \\
\hline Observations & \multicolumn{2}{|c|}{232} & \multicolumn{2}{|c|}{375} & \multicolumn{2}{|c|}{369} & \multicolumn{2}{|c|}{591} \\
\hline \multicolumn{9}{|l|}{ City: Guangzhou } \\
\hline Avg. Price $/ m^{2}$ & $5,119.98$ & $1,128.88$ & $6,404.62$ & $1,545.58$ & $12,345.76$ & $6,718.22$ & $14,276.31$ & $8,553.62$ \\
\hline Total Transactions & 22.03 & 41.01 & 23.06 & 34.09 & 19.64 & 41.87 & 15.44 & 35.98 \\
\hline Avg. Unit Size(m2) & 105.83 & 32.66 & 117.22 & 42.46 & 115.73 & 48.85 & 121.34 & 49.81 \\
\hline Observations & \multicolumn{2}{|c|}{61} & \multicolumn{2}{|c|}{208} & \multicolumn{2}{|c|}{573} & \multicolumn{2}{|c|}{1,120} \\
\hline \multicolumn{9}{|l|}{ City: Chengdu } \\
\hline Avg. Price $/ \mathrm{m}^{2}$ & $5,615.66$ & $2,166.52$ & $6,211.72$ & $2,341.34$ & $9,046.84$ & $3,914.80$ & $10,935.34$ & $6,208.18$ \\
\hline Total Transactions & 57.23 & 72.56 & 36.07 & 54.24 & 51.70 & 66.99 & 29.96 & 53.03 \\
\hline Avg. Unit Size $\left(m^{2}\right)$ & 123.82 & 53.43 & 113.70 & 50.17 & 99.17 & 42.45 & 96.50 & 42.54 \\
\hline Observations & \multicolumn{2}{|c|}{671} & \multicolumn{2}{|c|}{2,105} & \multicolumn{2}{|c|}{1,032} & \multicolumn{2}{|c|}{2,131} \\
\hline \multicolumn{9}{|l|}{ City: Qingdao } \\
\hline Avg. Price $/ m^{2}$ & $5,981.58$ & $4,004.82$ & $7,345.29$ & $4,805.90$ & $9,271.10$ & $8,415.40$ & $10,497.57$ & $8,708.98$ \\
\hline Total Transactions & 17.72 & 23.63 & 17.14 & 28.65 & 40.67 & 81.57 & 19.91 & 40.02 \\
\hline Avg. Unit Size $\left(m^{2}\right)$ & 135.59 & 66.43 & 125.29 & 56.00 & 125.99 & 51.79 & 110.80 & 39.77 \\
\hline Observations & \multicolumn{2}{|c|}{43} & \multicolumn{2}{|c|}{214} & \multicolumn{2}{|c|}{322} & \multicolumn{2}{|c|}{721} \\
\hline
\end{tabular}

Notes: This table provides the summary statistics of Avg. Price $/ \mathrm{m}^{2}$, total transactions, and average unit size of housing projects in each city before and after the implementation of the restrictions. 
Table A-3: Descriptive Statistics of Land Transactions by City (-6/+12 months)

\begin{tabular}{|c|c|c|c|c|c|c|c|c|}
\hline & \multicolumn{4}{|c|}{ Control } & \multicolumn{4}{|c|}{ Treat } \\
\hline & \multicolumn{2}{|c|}{ Before } & \multicolumn{2}{|c|}{ After } & \multicolumn{2}{|c|}{ Before } & \multicolumn{2}{|c|}{ After } \\
\hline & Mean & S.D & Mean & S.D & Mean & S.D & Mean & S.D \\
\hline Avg. Price $/ m^{2}$ & $1,763.56$ & $1,670.68$ & $1,268.25$ & $1,019.64$ & $2,321.28$ & $1,358.47$ & $1,628.39$ & $1,804.10$ \\
\hline Land Area & $58,154.86$ & $61,546.08$ & $43,354.24$ & $50,712.46$ & $35,401.18$ & $41,462.18$ & $28,042.84$ & $27,395.71$ \\
\hline Buildable Area & $158,250.31$ & $187,696.54$ & $140,487.78$ & $178,318.25$ & $113,542.01$ & $115,375.04$ & $82,192.26$ & $80,330.10$ \\
\hline \multicolumn{9}{|c|}{ City: Guangzhou } \\
\hline Avg. Price $/ m^{2}$ & $1,152.06$ & 711.74 & $1,085.44$ & 838.11 & $3,941.47$ & $3,176.56$ & $2,494.62$ & $1,730.89$ \\
\hline Land Area & $23,134.31$ & $19,325.09$ & $49,315.82$ & $49,367.04$ & $41,123.22$ & $58,960.65$ & $38,604.60$ & $39,558.73$ \\
\hline Buildable Area & $58,089.60$ & $40,365.40$ & $99,507.76$ & $101,780.44$ & $92,602.22$ & $121,864.97$ & $84,165.25$ & $83,887.93$ \\
\hline Land Area & $53,869.54$ & $46,649.04$ & $51,627.28$ & $44,017.80$ & $54,132.58$ & $51,604.08$ & $35,408.57$ & $27,810.83$ \\
\hline Buildable Area & $135,817.18$ & $123,877.76$ & $172,713.54$ & $177,069.20$ & $217,051.03$ & $255,899.65$ & $128,855.63$ & $96,308.38$ \\
\hline Observations & \multicolumn{2}{|c|}{106} & \multicolumn{2}{|c|}{113} & \multicolumn{2}{|c|}{36} & \multicolumn{2}{|c|}{40} \\
\hline \multicolumn{9}{|l|}{ City: Qingdao } \\
\hline Avg. Price $/ m^{2}$ & 615.56 & 444.66 & 954.58 & $1,188.76$ & $2,477.43$ & $2,067.35$ & $3,327.64$ & $10,397.90$ \\
\hline Land Area & $39,395.18$ & $38,922.06$ & $30,471.70$ & $28,978.79$ & $44,906.35$ & $38,507.62$ & $46,405.14$ & $50,634.42$ \\
\hline Buildable Area & $64,899.73$ & $75,740.32$ & $49,868.55$ & $51,659.81$ & $75,194.88$ & $58,274.81$ & $77,300.26$ & $83,764.80$ \\
\hline Observations & \multicolumn{2}{|c|}{137} & \multicolumn{2}{|c|}{180} & \multicolumn{2}{|c|}{46} & \multicolumn{2}{|c|}{72} \\
\hline
\end{tabular}

Notes: This table provides the summary statistics of Avg. Price $/ \mathrm{m}^{2}$ (=Avg. Price/Buildable Area), land area, and buildable area of land parcels in each city before and after the implementation of the policy. 
Table A-4: Descriptive Statistics of Housing Projects for Four Cities within 3km Border Bands (-6/+12 months)

\begin{tabular}{|c|c|c|c|c|c|c|c|c|}
\hline & \multicolumn{4}{|c|}{ Control } & \multicolumn{4}{|c|}{ Treat } \\
\hline & \multicolumn{2}{|c|}{ Before } & \multicolumn{2}{|c|}{ After } & \multicolumn{2}{|c|}{ Before } & \multicolumn{2}{|c|}{ After } \\
\hline & Mean & S.D & Mean & S.D & Mean & S.D & Mean & S.D \\
\hline Avg. Price $/ m^{2}$ & $5,565.70$ & $1,879.14$ & 6.316 .05 & $2,485.12$ & $8,834.60$ & $5,252.85$ & $11,096.26$ & $7,287.25$ \\
\hline Total Transactions & 50.35 & 68.13 & 33.03 & 49.35 & 44.62 & 70.16 & 24.64 & 47.09 \\
\hline Avg. Unit $\operatorname{Size}\left(m^{2}\right)$ & 115.77 & 46.87 & 106.33 & 46.63 & 99.73 & 41.32 & 96.23 & 41.84 \\
\hline Observations & \multicolumn{2}{|c|}{639} & \multicolumn{2}{|c|}{1,900} & \multicolumn{2}{|c|}{1,499} & \multicolumn{2}{|c|}{3,092} \\
\hline
\end{tabular}

Notes: This table provides the summary statistics of Avg. Price $/ \mathrm{m}^{2}$, total transactions, and average unit size of housing projects within $3 \mathrm{~km}$ border bands in each city before and after the implementation of the restrictions. 